\title{
In-vitro Antiviral Activity of Natural Products against Coronavirus Strains: A Systemic Review
}

\section{Sindhu KC}

School of Health and Allied Sciences, Pokhara University, Kaski, Nepal

Manoj Pandit ( $\square$ panditmanoj645@gmail.com)

Department of Pharmacology, Universal College of Medical Sciences, Tribhuvan University, Bhairahawa, Nepal https://orcid.org/0000-00017514-6563

Amit Kumar Shrivastava

Department of Pharmacology, Universal College of Medical Sciences, Tribhuvan University, Bhairahawa, Nepal https://orcid.org/0000-00028915-9186

\section{Systematic Review}

Keywords: Coronavirus, Natural Products, Antiviral Activity, Coronavirus Strains

Posted Date: August 24th, 2020

DOI: https://doi.org/10.21203/rs.3.rs-63691/v1

License: (c) (1) This work is licensed under a Creative Commons Attribution 4.0 International License. Read Full License 


\section{Abstract}

Coronavirus is a non-segmented, positive-sense RNA genome belonging to the family coronaviridae in the order Nidovirales Corona viral infections have created serious threats in the last couple of decades and recently claiming the death of thousands of human beings. Natural products provide a valuable and powerful resource of chemical compounds alkaloids, tannins, caffeine, biopterin, actinophnine, etc. displaying antiviral properties. The data was reviewed from various databases or search engines: PubMed, Science Direct, MedLine, Google Scholar, and Biomed central for published articles. The data inclusion criteria was natural products and their isolated and different synthetic compounds. Data duplication and titles or contents that do not meet the inclusion criteria and Reports on antiviral activities of natural products or their derivatives against other than CoV strains were excluded. We encountered 49 plants and 19 compound chemically defined natural molecules reported in the literature, which have evaluated for potent antiviral activity against different coronavirus strains. The listed plants and their compounds in this review are highly potent with promising results against coronavirus. These can be further screened for invasive tests and used for making different formulations or may be polyherbal formulations considering its safety profile and toxicity.

\section{Introduction}

Coronavirus (diameters of approximately $125 \mathrm{~nm}$ ) is a non-segmented, positive-sense RNA genome belonging to the family coronaviridae in the order Nidovirales [1, 2]. The genome packed inside a helical capsid formed by the nucleocapsid protein $(N)$ and further surrounded by an envelope. The viral envelope consists of four main structural proteins, i.e., spike protein (S) responsible for the formation of structure and attachment to the host receptor. The membrane protein $(M)$ responsible for giving the virion its shape helping to bind to the nucleocapsid, envelope protein (E) responsible for assembly, and release of the virus, which are required for pathogenesis and nucleocapsid protein $(\mathrm{N})$ responsible for replication [35].These four proteins are encoded within the 3 ' end of the viral genome. Some coronavirus also encodes an envelope-associated Hemagglutinin esterase protein that enhances spike protein to mediate cell entry and virus spread through the mucosa. Coronavirus can be classified into four genera, which are alpha, beta, gamma, and delta. Among them, alpha and beta infect mammals, whereas gamma infects avian species, and delta infects mammalian and avians both. The S-protein-receptor collaboration is the essential determinant for a coronavirus to contaminate a host animal category and oversees the infection's tissue tropism. Diverse coronaviruses use peptidases as their cell receptor. It is indistinct why peptidases are utilized, as passage happens even without the enzymatic area of these proteins. Numerous a-coronaviruses use aminopeptidase (APN) as their receptor, SARS-CoV and HCoV-NL63 use angiotensin-changing over enzyme 2 (ACE2) as their receptor, MHV enters through CEACAM1, and as of late recognized MERS-CoV ties to dipeptidyl-peptidase 4 (DPP4) to pick up section into the human cell [6-10].

The first coronavirus was discovered in 1930 when the infectious bronchitis virus caused an acute respiratory tract infection of domesticated chicken. In 1940, two more animal coronavirus, mouse hepatitis virus (MHV) [11, 12], and transmissible gastroenteritis virus isolated. Similarly, the first human coronavirus was identified in 1960 in the form of common cold among human beings. A study carried out in Canada in 2001 showed that more than 500 patients present with flu-like symptoms, on virological analyses, $3.6 \%$ of those cases were positive for the HCoV-NL63 strain by polymerase chain reaction [13]. Until 2002, coronavirus was considered a relatively simple, nonfatal virus; however, an outbreak in 2002-2003 in Guangdong province in China, which result in spread to many other countries, caused severe acute respiratory syndrome (SARS-CoV) and high mortality rate in over 1000 patient [14]. Since 2012 middle-east respiratory syndrome coronavirus (MERS-CoV) has infected more than 1700 people with a fatality rate of nearly $36 \%$ [15]. Since 2013, the porcine epidemic diarrhoea coronavirus (PEDV) has swept throughout the united states, causing an almost $100 \%$ fatality rate in piglets in less than a year [16]. At the end of 2019 , in Wuhan province of China, a novel coronavirus, i.e., COVID-19 outbreak, killed more than eighteen hundred and infected over seventy thousand individuals within the first fifty days of the epidemic $[17,18]$. In the past, SARS-CoV (2003) infected 8098 individuals with a mortality rate of 9\%, across 26 countries in the world whereas novel coronavirus (COVID-19 affected 4218212 individuals with a mortality rate of $3.4 \%$ across 116 countries, till the date of this writing which shows transmission rate of SARS-CoV-2 is higher than SARS-CoV. The reason behind it could be genetic recombination event at S protein in the RBD region of SARS-CoV-2, which may have enhanced its transmission ability [19].

The evolution of this virus demonstrates that coronavirus is not a stable virus and can adapt to the new environment through mutation and recombination with relative ease. Hence coronavirus are programmed to alter host range and tissue tropism efficiently to become more virulent, even lethal to human and animal by causing widespread respiratory, GI and CNS diseases in human and another animal. So, mutating this virus's mutating behaviour is becoming a great topic of research among drug developers, researchers, and scientists [20]. After the outbreak of MERS-CoV, SARS-CoV, and other respiratory like diseases bring high mortality and incidence of occurrence, which make it essential public health and economic issue due to which effective prevention is required. There are no specific vaccines or drugs or any formulations that can treat or cure novel coronavirus, and the researcher starts studying the alternative method by comparing the efficacy of the natural product. Resources against the various strains of these viruses with the standard one and emerging viral replication lead to the development and search of a distinct form of solutions from the natural product for drug discovery.

Plants have been the major source of many powerful drugs worldwide, and humans have been using it to heal different illnesses since prehistoric times. Thus, plants are considered the most important source of modern medicines that possess various therapeutic effects [21]. About $25 \%$ of

Page 2/16 
the medicines used worldwide are derived from plant sources [22]. The phytochemicals or metabolites (primary or secondary) are responsible for various pharmacological activities [23,24]. Its variation within the plant species confers the specificity in its therapeutic effects [25]. It has always been the challenge and opportunity for researchers to identify the phytochemicals responsible for the particular effects. The emergence of antiviral agents' importance from natural sources requires more research to develop more drugs to treat viral infection. Thus, we need to apply antiviral phyto-constitutes within medication therapy to achieve an increased pharmacological response. Herbal medicine is a promoting subject in medicine, and of course, we have to increase our knowledge about them. Therefore, in this review, an effort has been made to provide information about the medicinal plant that possesses antiviral activity against different coronavirus strains.

\section{Results And Discussion}

In common use today, many phytochemicals are associated with health benefits. Natural products have been the primary source of commercial medicines and drug leads until now. A recent survey revealed that $61 \%$ of the 877 drugs introduced worldwide could be traced to or inspired by natural products, out of roughly 350000 species of plants believed to exist, one-third of those yet to be discovered [26]. The search for antiviral materials from plants is inadequate compared to the investigation of the antimicrobial properties. Preliminary studies have shown that plants have an optimistic antiviral activity in vitro and in vivo [27]. However, the same plants can have different antiviral activities against RNA or DNA viruses, regardless of whether they are coated or not, and even against different types or strains of viruses [28, 29]. Many viral infectious diseases still cause high mortality. Although antiviral chemotherapy has made great strides, antivirals are still mandatory. The appearance of drug-resistant viruses during treatment poses a potential difficulty for effective therapy. New viral pathogens can also be discovered. Biologically active substances of plant origin have long been recognized as viral inhibitors. These antiviral compounds can be extracted from sources such as higher plants, which, for many reasons, have been discovered much less than the traditional ones [30].

There is a great need for readily available antiviral drugs at a reasonable cost with the least side effects. From now on, traditional drugs need to be investigated as new antivirals because many of these old drugs, which contain various plant metabolites, have strong antiviral activities [31]. Research into the antiviral potential of plants began in 1952, and 12 of the 288 plants are effective against influenza. Various screening studies have been conducted in recent years to determine the antiviral efficacy of natural products using in vitro and in vivo tests [32]. The fall of the SARS CoV and MERS CoV highlight the inadequacy of available treatment for life-threatening zoonotic CoV infection in humans. Still, there is no specific drug or vaccine that has been available for its treatment. The FDA (Food Drug Administration) has approved various drugs that inhibit entry and replication of MERS-CoV, SARS-CoV, or another human coronavirus in multiple cell lines; still, various plants and their compounds are on investigation for the search of the antiviral agent against coronavirus strain in this pandemic condition [33].

Table 1: Plants showing antiviral activity against different coronavirus strains 


\begin{tabular}{|c|c|c|c|c|c|c|c|c|c|c|c|}
\hline \multirow[t]{2}{*}{ S.N } & \multirow[t]{2}{*}{ Plant source } & \multirow[t]{2}{*}{ Families } & \multirow{2}{*}{$\begin{array}{l}\text { Parts } \\
\text { used }\end{array}$} & \multirow[t]{2}{*}{ Culture cells } & \multirow{2}{*}{$\begin{array}{l}\text { Virus/ } \\
\text { strain }\end{array}$} & \multirow[t]{2}{*}{ Method applied } & \multirow[t]{2}{*}{ Compounds responsible } & \multicolumn{2}{|l|}{ Results } & \multirow[t]{2}{*}{ Conclusion } & \multirow[t]{2}{*}{ Ref. } \\
\hline & & & & & & & & Test Samples & Standard & & \\
\hline 1 & Allium porrum & Alliacease & ND & $\begin{array}{l}\text { Vero cell } \\
\text { ATCC line }\end{array}$ & $\begin{array}{l}\text { SARS-CoV } \\
\text { Frankfurt } \\
1 \text { strain }\end{array}$ & $\begin{array}{l}\text { CPE based } \\
\text { Antiviral assay }\end{array}$ & Mannose specific lectin & $\begin{array}{l}\text { Most potent against the } \\
\text { SARS-CoV induced CPE with } \\
\text { EC50 }(0.45 \mu \mathrm{g} / \mathrm{ml}) \\
\text { CC50 }(>100) \text { and SI }(222)\end{array}$ & ND & $\begin{array}{l}\text { Probably } \\
\text { interfering } \\
\text { with the } \\
\text { glycons on the } \\
\text { spike protein } \\
\text { during virus } \\
\text { entry and virus } \\
\text { release }\end{array}$ & [34] \\
\hline 2 & Urtica dioica & Urticaceae & ND & $\begin{array}{l}\text { Vero cell } \\
\text { ATCC line }\end{array}$ & $\begin{array}{l}\text { SARS-CoV } \\
\text { frankfurt } \\
1 \text { strain }\end{array}$ & $\begin{array}{l}\text { CPE based } \\
\text { Antiviral assay }\end{array}$ & $\begin{array}{l}\text { N-acetyl glucosamine - } \\
\text { specific lectin }\end{array}$ & $\begin{array}{l}\text { Markely active against the } \\
\text { SARS-CoV with } \\
\mathrm{EC}_{50}(1.3 \pm 0.1 \mu \mathrm{g} / \mathrm{ml}) \text {, } \\
\mathrm{CC}_{50}(>100) \text { and SI }(>77)\end{array}$ & ND & $\begin{array}{l}\text { Probably } \\
\text { interfering } \\
\text { with the } \\
\text { glycons on the } \\
\text { spike protein } \\
\text { during virus } \\
\text { entry and virus } \\
\text { release }\end{array}$ & [34] \\
\hline 3 & $\begin{array}{l}\text { Hippeastrum } \\
\text { hybrid }\end{array}$ & Amaryllis & ND & $\begin{array}{l}\text { Vero cell } \\
\text { ATCC line }\end{array}$ & $\begin{array}{l}\text { SARS-CoV } \\
\text { frankfurt } \\
1 \text { strain }\end{array}$ & $\begin{array}{l}\mathrm{CPE} \text { based } \\
\text { Antiviral assay } \\
\text {,Virus entry } \\
\text { assay }\end{array}$ & Mannose -specific lectin & $\begin{array}{l}\text { Shows marked inhibition } \\
\text { against SARS-CoV with } \\
\mathrm{EC}_{50}(3.2 \pm 2.8 \quad \mu \mathrm{g} / \mathrm{ml}) \\
\mathrm{CC}_{50}(>100) \text { and SI }(>31.3) \\
\text { Showed active at } 4 \text { degree } \mathrm{C} \\
\text { having } 2 \text { time more active } \\
\left(\mathrm{EC}_{50}=2.5 \mu \mathrm{g} / \mathrm{ml}\right) \text { in compare } \\
\text { to attachement and } \\
\text { penetration at 37degree } \\
\text { Celsius } \mathrm{EC}_{50}(5.2 \mu \mathrm{g} / \mathrm{ml})\end{array}$ & ND & $\begin{array}{l}\text { Probably } \\
\text { interfering } \\
\text { with the } \\
\text { glycons on the } \\
\text { spike protein } \\
\text { during virus } \\
\text { entry and virus } \\
\text { release }\end{array}$ & [34] \\
\hline 4 & $\begin{array}{l}\text { Nicotiana } \\
\text { tobacum }\end{array}$ & Solanacea & ND & $\begin{array}{l}\text { Vero cell } \\
\text { ATCC line }\end{array}$ & $\begin{array}{l}\text { SARS-CoV } \\
\text { frankfurt } \\
1 \text { strain }\end{array}$ & $\begin{array}{l}\text { CPE based } \\
\text { Antiviral assay }\end{array}$ & $\begin{array}{l}\text { N-acetyl glucosamine } \\
\text { specific lectin }\end{array}$ & $\begin{array}{l}\text { Markely active against the } \\
\text { SARS-CoV with } \\
\mathrm{EC}_{50}(1.7 \pm 0.3 \mu \mathrm{g} / \mathrm{ml}) \quad \text { and } \\
\mathrm{CC}_{50}(>100) \text {, SI }(>59)\end{array}$ & ND & $\begin{array}{l}\text { Probably } \\
\text { interfering } \\
\text { with the } \\
\text { glycons on the } \\
\text { spike protein } \\
\text { during virus } \\
\text { entry and virus } \\
\text { release }\end{array}$ & [34] \\
\hline 5 & Laurus nobilis & Lauraceae & Berry & Vero cell & SARS-CoV & $\begin{array}{l}\text { Cytotoxicity } \\
\text { assay } \\
\text { Antiviral assay }\end{array}$ & ND & $\begin{array}{lr}\text { Strong antiviral activity } \\
\text { against SARS-CoV } & \text { with } \\
\mathrm{IC}_{50}=120 \pm 1.2 \mu \mathrm{g} / \mathrm{ml} & \\
\text { And SI value } & (4.2) \\
\mathrm{TC}_{50}(500 \pm 1.02) & \text { when } \\
\text { compare with positive } \\
\text { control }\end{array}$ & $\begin{array}{l}\text { Where positive } \\
\text { control } \\
\text { glycyrrhizin } \\
\text { shown IC } \text { IC }_{50} \\
641 \mu \mathrm{g} / \mathrm{ml} \text { with } \\
\text { SI value (1.2) }\end{array}$ & ND & [35] \\
\hline 6 & Thuja orientalis & Cupressaceae & Fruit & Vero cell & SARS-CoV & $\begin{array}{l}\text { Cytotoxicity } \\
\text { Antiviral assay }\end{array}$ & ND & $\begin{array}{l}\text { Certain activitiy against } \\
\text { SARS-CoV with } \\
\mathrm{IC}_{50} 130 \mu \mathrm{\mu g} / \mathrm{ml} \text { and SI value } \\
(3.8), \mathrm{TC}_{50}(>1000)\end{array}$ & $\begin{array}{l}\text { Where positive } \\
\text { control } \\
\text { glycyrrhizin } \\
\text { shown IC } 50 \\
641 \mu \mathrm{g} / \mathrm{ml} \text { with } \\
\text { SI value (1.2) }\end{array}$ & ND & [35] \\
\hline 7 & $\begin{array}{l}\text { Calophyllum } \\
\text { blancoi }\end{array}$ & Guttiferae & Roots & MRC-5 & $\begin{array}{l}\mathrm{HCoV} \\
229 \mathrm{E}\end{array}$ & $\begin{array}{l}\text { CPE based } \\
\text { Antiviral assay }\end{array}$ & Blanco xanthone & $\begin{array}{l}\text { Potential candidate for the } \\
\text { treatment of Corona virus } \\
\text { infection with } \mathrm{EC}_{50} 3 \mu \mathrm{g} / \mathrm{ml}\end{array}$ & $\begin{array}{l}\text { Actinomycin D } \\
\left(\mathrm{IC}_{50}\right. \\
0.02 \mu \mathrm{g} / \mathrm{ml})\end{array}$ & ND & [36] \\
\hline 8 & $\begin{array}{l}\text { Broussonetia } \\
\text { papyrifera }\end{array}$ & Moraceae & Roots & $\begin{array}{l}\text { E. coliBL21 } \\
\text { HIT } \\
\text { competent } \\
\text { cells }\end{array}$ & $\begin{array}{l}\text { MERS-CoV } \\
3 \mathrm{Cl} \text { Pro } \\
\text { MERS CoV } \\
\text { Pl pro } \\
\text { SARS CoV } \\
\text { 3CL pro } \\
\text { SARS-CoV } \\
\text { PL pro }\end{array}$ & $\begin{array}{l}\text { Antiviral assay } \\
\text { by Protease } \\
\text { inhibition } \\
\text { method }\end{array}$ & $\begin{array}{l}\text { Broussochalcone B ( against } \\
\text { MERS-cov } 3 \mathrm{Cl} \text { pro) } \\
\text { Biphenyl propanoid (against } \\
\text { MERS-CoV PL pro) } \\
\text { Flavan 5(against SARS-CoV } \\
3 \mathrm{Cl} \text { pro) } \\
\text { Prenylated flavone (against } \\
\text { SARS-CoV PL pro) }\end{array}$ & $\begin{array}{l}\text { Showed effective } \\
\mathrm{IC}_{50} 27.9 \mu \mathrm{m} \text { against MERS- } \\
\mathrm{CoV} 3 \mathrm{Cl} \text { pro Showed most } \\
\text { potent } \mathrm{IC}_{50} 39.5 \mu \mathrm{m} \text { against } \\
\text { MERS-CoV PL pro Showed } \\
\text { most potent } \mathrm{IC}_{50} 30.2 \pm 6.8 \\
\text { against SARS-CoV } 3 \mathrm{CL} \text { pro } \\
\text { Showed highest inhibitory } \\
\text { activity against SARS-CoV } \\
\text { PL pro with } \mathrm{IC}_{50} 3.7 \mu \mathrm{m}\end{array}$ & $\begin{array}{l}\text { Quercetin } \\
\text { shows } \mathrm{IC}_{50} \\
(52.7 \mu \mathrm{m}) \\
\text { against SARS- } \\
\text { CoV 3CL pro }\end{array}$ & $\begin{array}{l}\text { May be prenyl } \\
\text { group form } \\
\text { strong } \\
\text { hydrophobic } \\
\text { interaction } \\
\text { with enzyme }\end{array}$ & [37] \\
\hline 9 & $\begin{array}{l}\text { Paulownia } \\
\text { tomentosa }\end{array}$ & Paulowniaceae & Fruits & E. coli & $\begin{array}{l}\text { SARS-CoV } \\
\text { Pl pro }\end{array}$ & $\begin{array}{l}\text { Protease } \\
\text { inhibitiom } \\
\text { assay(flurogenic } \\
\text { assay) }\end{array}$ & Compound (1-12) flavonoids & $\begin{array}{l}\text { Showed inhibition of } \mathrm{Pl} \text { pro } \\
\text { in a dose dependent manner } \\
\text { with } \mathrm{IC}_{50} \text { range between } 5.0 \\
\text { and } 14.4 \mu \mathrm{m}\end{array}$ & ND & $\begin{array}{l}\text { Compound } \\
\text { having dihydro- } \\
2 \mathrm{H} \text {-pyran } \\
\text { group shows } \\
\text { better } \\
\text { inhibition and } \\
\text { may be all this } \\
\text { compound bind } \\
\text { allosteric site }\end{array}$ & [38] \\
\hline
\end{tabular}




\begin{tabular}{|c|c|c|c|c|c|c|c|c|c|c|c|}
\hline & & & & & & & & & & $\begin{array}{l}\text { of the protease } \\
\text { enzyme for } \\
\text { inhibition of } \\
\text { their activity }\end{array}$ & \\
\hline 10 & $\begin{array}{l}\text { Psoralea } \\
\text { corylifolia }\end{array}$ & Fabaceae & Seeds & $\begin{array}{l}\text { BL21(DE3) } \\
\text { E. coli }\end{array}$ & $\begin{array}{l}\text { SARS-CoV } \\
\text { PLpro }\end{array}$ & $\begin{array}{l}\text { Protease } \\
\text { inhibition assay }\end{array}$ & Compound ( 1-6) & $\begin{array}{l}\text { All this compound showed } \\
\text { inhibitory action against } \\
\text { protease enzyme with } \\
\mathrm{IC}_{50} \text { value of Bavachinin } \\
(38.4 \pm 2.4) \\
\text { neobavaisoflavone }(18.3 \pm 1.1) \text {, } \\
\text { isobavachalcone }(7.3 \pm 0.8) \\
\text {,methyl } \\
\text { bavachalcone }(101 \pm 1.2) \\
\text { psoralidin }(4.2 \pm 1.0) \text {, corylifol } \\
\text { A(32.3 } \pm 3.2) \text { when } \\
\text { compared with control }\end{array}$ & $\begin{array}{l}\text { The } \mathrm{IC}_{50} \text { value } \\
\text { for psoralen as } \\
\text { control >150 } \\
\text { against SARS- } \\
\mathrm{CoV} \mathrm{Pl} \text { pro } \\
\text { enzyme. }\end{array}$ & $\begin{array}{l}\text { Compound } \\
\text { Isobavachalcole } \\
\text { and psoraladin } \\
\text { showed } \\
\text { reversible } \\
\text { mixed type of } \\
\text { mechanism for } \\
\text { inhibition of } \\
\text { enzyme and } \\
\text { coumestrol } \\
\text { (compound 5) } \\
\text { group of } \\
\text { compound } \\
\text { show most } \\
\text { potent } \\
\text { inhibitor } \\
\text { against } \\
\text { enzyme. }\end{array}$ & [39] \\
\hline 11 & $\begin{array}{l}\text { Juniperus } \\
\text { oxycedrus }\end{array}$ & Cupressaceae & Berry & Vero cell & SARS-CoV & $\begin{array}{l}\text { Cytotoxicity } \\
\text { assay, } \\
\text { Antiviral assay }\end{array}$ & & $\begin{array}{l}\text { Certain activitiy against } \\
\text { SARS-CoV with } \mathrm{IC}_{50} \\
270 \mu \mathrm{g} / \mathrm{ml} \text { and SI value } \\
(3.7), \mathrm{TC}_{50}(1000 \pm 1.7)\end{array}$ & $\begin{array}{l}\text { Where positive } \\
\text { control } \\
\text { glycyrrhizin } \\
\text { shown IC } \mathrm{IC}_{50} \\
641 \mu \mathrm{g} / \mathrm{ml} \text { with } \\
\text { SI value (1.2) }\end{array}$ & & [35] \\
\hline 12 & $\begin{array}{l}\text { Sambus } \\
\text { formosana }\end{array}$ & Adoxaceae & Stem & $\begin{array}{l}\text { LLC-MK2 } \\
\text { cells }\end{array}$ & $\begin{array}{l}\mathrm{HCoV}- \\
\mathrm{NL63}\end{array}$ & $\begin{array}{l}\text { Virucidal assay } \\
\text { Attachement } \\
\text { assay } \\
\text { Plaque assay }\end{array}$ & $\begin{array}{l}\text { Caffeic acid (most prominet } \\
\text { result) }\end{array}$ & $\begin{array}{l}\text { Extract show antiviral } \\
\text { activity } \\
\mathrm{IC}_{50}(1.75 \mu \mathrm{g} / \mathrm{ml}) \text { for virus } \\
\text { yield, } \mathrm{IC}_{50}(4.67 \mu \mathrm{g} / \mathrm{ml}) \text { for } \\
\text { plaque formation, } \\
\mathrm{IC}_{50}(15.75 \mu \mathrm{g} / \mathrm{ml}) \text { for virus } \\
\text { attachment } \\
\text { Compound show antiviral } \\
\text { activity with } \mathrm{IC}_{50}(3.54 \mu \mathrm{g}) \\
\text { for virus yield } \\
\mathrm{IC}_{50}(3.40 \mu \mathrm{m}) \text { for plaque } \\
\text { formation and } \mathrm{IC}_{50}(8.10 \mu \mathrm{m}) \\
\text { for virus attachment assay }\end{array}$ & ND & $\begin{array}{l}\text { Caffeic acid } \\
\text { may interfere } \\
\text { the binding } \\
\text { interation of } \\
\text { HCOV-NL63 } \\
\text { with heparan } \\
\text { sulfate } \\
\text { proteogylcans } \\
\text { and ACE2 } \\
\text { receptor on the } \\
\text { cell surface }\end{array}$ & [40] \\
\hline 13 & Lycoris radiate & Amaryllidaceae & $\begin{array}{l}\text { Stem } \\
\text { cortex }\end{array}$ & $\begin{array}{l}\text { Vero E6 / } \\
\text { HEPG2 line }\end{array}$ & $\begin{array}{l}\text { BJOO1 } \\
\text { BJOO6 }\end{array}$ & $\mathrm{CPE} / \mathrm{MTS}$ as say & Lycorine & $\begin{array}{l}\text { SI ( } 370 \text { ) for BJ001 strain } \\
\text { and SI }(422) \text { for BJ006 strain } \\
\text { by extract } \\
\text { Lycorine showed SI value } \\
>900 \\
\text { ( this data is sufficient to } \\
\text { show this compound have } \\
\text { antiviral activity against } \\
\text { SARS-CoV }\end{array}$ & $\begin{array}{l}\text { Interferon a } \\
\text { showed } \\
\text { value }(>151) \\
\text { for BJ001 and } \\
\text { SI value (>170) } \\
\text { for BJ006 }\end{array}$ & $\begin{array}{l}\text { May be by } \\
\text { interacting } \\
\text { with expressed } \\
\text { viral protein / } \\
\text { antigen }\end{array}$ & [41] \\
\hline 14 & $\begin{array}{l}\text { Artemisia } \\
\text { annua }\end{array}$ & Asteraceae & $\begin{array}{l}\text { Whole } \\
\text { plant }\end{array}$ & $\begin{array}{l}\text { Vero E6 I } \\
\text { HEPG2 line }\end{array}$ & $\begin{array}{l}\text { BJOO1 } \\
\text { BJOO6 }\end{array}$ & CPE /MTS as say & ND & $\begin{array}{l}\mathrm{SI}=31 \text { (against } \mathrm{BJ} 001 \text { ) } \\
\mathrm{SI}=27 \text { ( against } \mathrm{BJ} 006 \text { ) } \\
\text { That shows it have certain } \\
\text { amount of antiviral activity } \\
\text { against SARS-CoV strain in } \\
\text { vero cells }\end{array}$ & $\begin{array}{l}\text { Interferon a } \\
\text { showed SI } \\
\text { value (>151) } \\
\text { for BJ001 and } \\
\text { SI value }(>170) \\
\text { for BJ006 }\end{array}$ & $\begin{array}{l}\text { Can be } \\
\text { moderate } \\
\quad \text { antiviral } \\
\text { activities } \\
\text { against this } \\
\text { strain of virus }\end{array}$ & [41] \\
\hline 15 & Pyrrosia lingua & Polypodiaceae & Leaf & $\begin{array}{l}\text { Vero E6 / } \\
\text { HEPG2 line }\end{array}$ & $\begin{array}{l}\text { BJOO1 } \\
\text { BJOO6 }\end{array}$ & $\mathrm{CPE} / \mathrm{MTS}$ as say & ND & $\begin{array}{l}\mathrm{SI}=55 \text { (against BJ001) } \\
\mathrm{SI}=59 \text { ( against BJ006) } \\
\text { That shows it have certain } \\
\text { amount of antiviral activity } \\
\text { against SARS-CoV strain in } \\
\text { vero cells }\end{array}$ & $\begin{array}{l}\text { Interferon a } \\
\text { showed SI } \\
\text { value (>151) } \\
\text { for BJ001 and } \\
\text { SI value }(>170) \\
\text { for BJ006 }\end{array}$ & ND & [41] \\
\hline 16 & $\begin{array}{l}\text { Lindera } \\
\text { aggregata }\end{array}$ & Lauraceae & Root & $\begin{array}{l}\text { Vero E6 / } \\
\text { HEPG2 line }\end{array}$ & $\begin{array}{l}\text { BJOO1 } \\
\text { BJOO6 }\end{array}$ & $\mathrm{CPE} / \mathrm{MTS}$ assay & ND & $\begin{array}{l}\mathrm{SI}=16 \text { (against BJ001) } \\
\mathrm{SI}=17 \text { ( against BJ006) } \\
\text { That shows it } \\
\text { Have certain amount of } \\
\text { antiviral activity against } \\
\text { SARS-CoV strain in vero } \\
\text { cells. }\end{array}$ & $\begin{array}{l}\text { Interferon a } \\
\text { showed SI } \\
\text { value (>151) } \\
\text { for BJ001 and } \\
\text { SI value }(>170) \\
\text { for BJ006 }\end{array}$ & & [41] \\
\hline 17 & $\begin{array}{l}\text { Isatis } \\
\text { indigotica }\end{array}$ & Brassicaceae & Root & Vero cells & $\begin{array}{l}\text { SARS-CoV } \\
\text { 3CL pro }\end{array}$ & $\begin{array}{l}\text { Cell based } \\
\text { cleavage assay }\end{array}$ & Sinigrin & $\begin{array}{l}\text { With } \mathrm{IC}_{50}=217 \mu \mathrm{g} / \mathrm{ml} \text { was } \\
\text { more efficient in blocking the } \\
\text { cleavage processing of the }\end{array}$ & ND & $\begin{array}{l}\text { Sinigrin block } \\
\text { the cleavage } \\
\text { process of the }\end{array}$ & [42] \\
\hline
\end{tabular}

Page 5/16 


\begin{tabular}{|c|c|c|c|c|c|c|c|c|c|c|c|}
\hline & & & & & & & & $\begin{array}{l}\text { 3CL pro then other } \\
\text { compound present on extract }\end{array}$ & & $\begin{array}{l}3 \mathrm{Cl} \text { pro in cell } \\
\text { based assay } \\
\text { where aloe } \\
\text { emodin and } \\
\text { hesperetin } \\
\text { inhibit } \\
\text { cleavage } \\
\text { activity of } 3 \mathrm{Cl} \\
\text { pro in dose } \\
\text { dependent } \\
\text { manner }\end{array}$ & \\
\hline 18 & $\begin{array}{l}\text { Torreya } \\
\text { nucifera }\end{array}$ & Taxaceae & leaves & & $\begin{array}{l}\text { SARS-CoV } \\
\text { 3CL pro }\end{array}$ & $\begin{array}{l}\text { FRET analysis } \\
\text { Dockling } \\
\text { analysis }\end{array}$ & $\begin{array}{l}\text { Biflavone } \\
\text { amentoflavone } \\
\text { Apigenin }\end{array}$ & $\begin{array}{l}\text { Inhibitory effect of extract on } \\
\text { enzyme about } 62 \% \text { at } \\
100 \mu \mathrm{g} / \mathrm{ml} \text {. } \\
\text { Active compound showed } \\
\text { potent } 3 \mathrm{CL} \text { pro inhibitory } \\
\text { effect at } \\
\mathrm{IC}_{50}=8.3 \mu \mathrm{g} / \mathrm{ml} \\
\text { Apigenin } \mathrm{IC}_{50}=280.8 \mu \mathrm{g} / \mathrm{ml} \\
\text { show } 3 \mathrm{Cl} \text { pro inhibitory } \\
\text { effect respectable. }\end{array}$ & $\begin{array}{l}\text { Abietic acid } \\
\text { showed } \\
58.0 \pm 4.8 \% \\
\text { inhibition with } \\
\mathrm{IC}_{50}=189.1 \pm \\
15.5 \mu \mathrm{m}\end{array}$ & $\begin{array}{l}\text { May be due to } \\
\text { presence of } \\
\text { Apigenin } \\
\text { moiety at } \\
\text { position C-3' } \\
\text { position of } \\
\text { flavone as } \\
\text { biflavone has } \\
\text { an effect of 3CL } \\
\text { pro inhibitory } \\
\text { activity }\end{array}$ & [43] \\
\hline 19 & $\begin{array}{l}\text { Cimicifuga } \\
\text { rhizoma }\end{array}$ & Ranuculacease & ND & $\begin{array}{l}\text { DBT cells/ } \\
\text { vero cells }\end{array}$ & $\begin{array}{l}\text { MHV-A59/ } \\
\text { PEDV }\end{array}$ & $\begin{array}{l}\text { Cell viability } \\
\text { assay, } \\
\text { Plaque assay, }\end{array}$ & ND & $\begin{array}{l}\mathrm{EC}_{50} \text { value } \\
\mathrm{SI}(12.3) \text { for MHV-A59 } \\
\text { replication and also } \\
\text { decreases PEDV production } \\
\text { in dose dependent manner }\end{array}$ & ND & ND & [44] \\
\hline 20 & Meliae cortex & Meliaceae & ND & $\begin{array}{l}\text { DBT cells / } \\
\text { vero cells }\end{array}$ & $\begin{array}{l}\text { MHV- } \\
\text { A59/PEDV }\end{array}$ & $\begin{array}{l}\text { Cell viability } \\
\text { assay, } \\
\text { Plaque assay }\end{array}$ & ND & $\begin{array}{l}\mathrm{EC}_{50} \text { value } 13.0+/ \_1.4 \mu \mathrm{g} / \mathrm{m} \text {, } \\
\mathrm{SI}(25.6) \text { for MHV-A59 and } \\
\text { decreases PEDV production } \\
\text { in dose dependent manner }\end{array}$ & ND & $\begin{array}{l}\text { May be due to } \\
\text { the inhibition } \\
\text { of RNA } \\
\text { dependent } \\
\text { RNA } \\
\text { polymerase }\end{array}$ & [44] \\
\hline 21 & $\begin{array}{l}\text { Coptidis } \\
\text { rhizoma }\end{array}$ & Cibotiaceae & ND & $\begin{array}{l}\text { DBT cells/ } \\
\text { vero cells }\end{array}$ & $\begin{array}{l}\text { MHV- } \\
\text { A59/PEDV }\end{array}$ & $\begin{array}{l}\text { Cell viability } \\
\text { assay, } \\
\text { Plaque assay }\end{array}$ & ND & $\begin{array}{l}\mathrm{EC}_{50} \text { value } 2.0+/ 0.5 \mu \mathrm{g} / \mathrm{m} \text {. } \\
\mathrm{SI}-(34.9) \text { for MHV -A59 } \\
\text { strain and also decreases } \\
\text { PEDV production in dose } \\
\text { dependent manner }\end{array}$ & ND & $\begin{array}{l}\text { May be due to } \\
\text { the inhibition } \\
\text { of RNA } \\
\text { dependent } \\
\text { RNA } \\
\text { polymerase }\end{array}$ & [44] \\
\hline 22 & $\begin{array}{l}\text { Phellodendron } \\
\text { cortex }\end{array}$ & Rutaceae & ND & $\begin{array}{l}\text { DBT cells/ } \\
\text { vero cells }\end{array}$ & $\begin{array}{l}\text { MHV- } \\
\text { A59/PEDV }\end{array}$ & $\begin{array}{l}\text { Cell viability } \\
\text { assay, } \\
\text { Plaque assay }\end{array}$ & ND & $\begin{array}{l}\mathrm{EC}_{50} \text { value } 10.4 \pm 2.2 \mu \mathrm{g} / \mathrm{ml} \text {, } \\
\mathrm{SI}(13.4) \text { for } \mathrm{MHV} \text { A59 and } \\
\text { also decreases PEDV } \\
\text { production in dose } \\
\text { dependent manner }\end{array}$ & ND & $\begin{array}{l}\text { May be due to } \\
\text { the inhibition } \\
\text { of RNA } \\
\text { dependent } \\
\text { RNA } \\
\text { polymerase }\end{array}$ & [44] \\
\hline 23 & $\begin{array}{l}\text { Sophora } \\
\text { subprostrata } \\
\text { radix }\end{array}$ & Fabaceae & ND & $\begin{array}{l}\text { DBT cells/ } \\
\text { vero cells }\end{array}$ & $\begin{array}{l}\text { MHV- } \\
\text { A59/PEDV }\end{array}$ & $\begin{array}{l}\text { Cell viability } \\
\text { assay, } \\
\text { Plaque assay }\end{array}$ & ND & $\begin{array}{lll}\mathrm{EC}_{50} \text { value } & 27.5 \pm 1.1 \mu \mathrm{g} / \mathrm{ml} \\
\mathrm{SI}(11.1) \text {,for } & \mathrm{MHV} & -\mathrm{A} 59 \\
\text { and also decreased } & \mathrm{PEDV} \\
\text { production in } & \text { dose } \\
\text { dependent manner }\end{array}$ & ND & $\begin{array}{l}\text { May be due to } \\
\text { the inhibition } \\
\text { of RNA } \\
\text { dependent } \\
\text { RNA } \\
\text { polymerase }\end{array}$ & [44] \\
\hline 24 & Torilis fructus & Apiaceae & ND & $\begin{array}{l}\text { DBT cells/ } \\
\text { vero cell line }\end{array}$ & $\begin{array}{l}\text { MHV- } \\
\text { A59/PEDV }\end{array}$ & $\begin{array}{l}\text { Plaque as say, } \\
\text { viability assay }\end{array}$ & ND & $\begin{array}{l}\text { Extract reduced intracellular } \\
\text { viral MRNA7 }(93 \%) \text {, protein } \\
\text { ( } 100 \% \text { )and production and } \\
\text { replication of virus with } \\
\mathrm{EC}_{50}=0.8 \pm 0.0 \text { and } \\
\text { SI value } 195.6\end{array}$ & 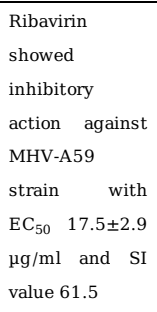 & $\begin{array}{l}\text { Antiviral } \\
\text { activity may be } \\
\text { due to } \\
\text { inducing COX2 } \\
\text { expression } \\
\text { through the } \\
\text { activation of } \\
\text { ERK and P38 } \\
\text { or ERK alone }\end{array}$ & [45] \\
\hline 25 & $\begin{array}{l}\text { Acanthopanacis } \\
\text { cortex }\end{array}$ & Araliaceae & ND & $\begin{array}{l}\text { DBT cells / } \\
\text { vero cell line }\end{array}$ & $\begin{array}{l}\text { MHV- } \\
\text { A59/PEDV }\end{array}$ & $\begin{array}{l}\text { Plaque assay, } \\
\text {,cell viability } \\
\text { assay }\end{array}$ & ND & $\begin{array}{l}\text { Extract reduced intracellular } \\
\text { viral MRNA7 }(90 \%) \text {, protein } \\
\text { ( } 98 \% \text { ) and production and } \\
\text { replication of virus with } \\
\text { EC }_{50}=0.9 \pm 0.1 \mathrm{\mu g} / \mathrm{ml} \text { and SI } \\
\text { value } 188.9\end{array}$ & 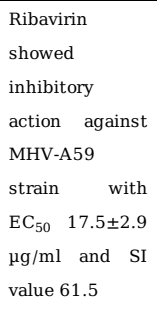 & $\begin{array}{l}\text { Antiviral } \\
\text { activity may be } \\
\text { due to } \\
\text { inducing COX2 } \\
\text { expression } \\
\text { through the } \\
\text { activation of } \\
\text { ERK and P38 } \\
\text { or ERK alone }\end{array}$ & [45] \\
\hline 26 & Sophorae radix & Fabaceae & ND & $\begin{array}{l}\text { DBT cells/ } \\
\text { vero cell line }\end{array}$ & $\begin{array}{l}\text { MHV- } \\
\text { A59/PEDV }\end{array}$ & $\begin{array}{l}\text { Plaque assay, } \\
\text { viability assay }\end{array}$ & ND & $\begin{array}{l}\text { Extract } \\
\text { viral } \\
\text { MRNA7 }(78 \%) \\
\text { protein }\end{array}$ & $\begin{array}{l}\text { Ribavirin } \\
\text { showed } \\
\text { inhibitory }\end{array}$ & ND & [45] \\
\hline
\end{tabular}




\begin{tabular}{|c|c|c|c|c|c|c|c|c|c|c|c|}
\hline & & & & & & & & $\begin{array}{l}\text { production and replication of } \\
\text { virus with } \quad \mathrm{EC}_{50}=0.8 \pm \\
0.2 \mu \mathrm{g} / \mathrm{ml} \text { and SI value } 696.0\end{array}$ & $\begin{array}{l}\text { action against } \\
\text { MHV-A59 } \\
\text { strain with } \\
\mathrm{EC}_{50} 17.5 \pm 2.9 \\
\mu \mathrm{g} / \mathrm{ml} \text { and SI } \\
\text { value } 61.5\end{array}$ & & \\
\hline 27 & $\begin{array}{l}\text { Sanguisorbae } \\
\text { radix }\end{array}$ & Rosaceae & ND & $\begin{array}{l}\text { DBT cells / } \\
\text { vero cell line }\end{array}$ & $\begin{array}{l}\text { MHV- } \\
\text { A59/PEDV }\end{array}$ & $\begin{array}{l}\text { Plaque assay, } \\
\text { cell viability } \\
\text { assay }\end{array}$ & ND & $\begin{array}{l}\text { Extract reduced intracellular } \\
\text { viral protein ( } 45 \%) \text { and } \\
\text { production and replication of } \\
\text { virus with } \mathrm{EC}_{50}=0.9 \pm 0.1 \\
\mu \mathrm{g} / \mathrm{ml} \text { and SI value } 105.0\end{array}$ & 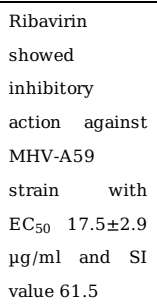 & $\begin{array}{l}\text { Reduce } \mathrm{CoV} \\
\text { production } \\
\text { partly as a } \\
\text { result of } \\
\text { decreased in } \\
\text { protein } \\
\text { synthesis }\end{array}$ & {$[45]$} \\
\hline 28 & $\begin{array}{l}\text { Gentiana } \\
\text { scabra }\end{array}$ & Gentianaceae & Rhizome & Vero E6 cells & $\begin{array}{l}\text { SARS-COV } \\
\text { 3CL pro }\end{array}$ & $\begin{array}{l}\text { CPE assay, cell } \\
\text { proliferation } \\
\text { assay,viral } \\
\text { replication } \\
\text { assay, MTT } \\
\text { assay( cell } \\
\text { based } \\
\text { assay),protease } \\
\text { inhibition assay }\end{array}$ & ND & $\begin{array}{l}\text { In GSH fraction, Inhibitory } \\
\text { cytopathogenic effect at } 25 \\
\text { to } 200 \mu \mathrm{g} / \mathrm{ml} \\
\text { Inhibition of viral replication } \\
\mathrm{EC}_{50}=8.70 \mu \mathrm{g} / \mathrm{ml} \text { at } \\
\text { concentration } 0.1-10 \mu \mathrm{\mu g} / \mathrm{ml} \\
\text { with SI ( }>57.5 \text { ) } \\
\text { Inhibition of } 3 \mathrm{CL} \text { protease } \\
\text { enzyme at IC } \mathrm{C}_{50}(>50 \mu \mathrm{\mu g} / \mathrm{ml} \text { ) } \\
\text {, with biological safe for host } \\
\text { cell in concentration } 10 \text { to } \\
500 \mu \mathrm{g} / \mathrm{ml}\end{array}$ & 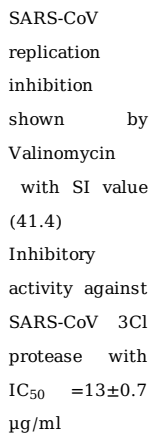 & ND & [46] \\
\hline 29 & $\begin{array}{l}\text { Dioscorea } \\
\text { batatas }\end{array}$ & Dioscoreae & Tuber & Vero E6 cells & $\begin{array}{l}\text { SARS-CoV } \\
\text { 3CL pro }\end{array}$ & $\begin{array}{l}\text { CPE assay, cell } \\
\text { proliferation } \\
\text { assay,viral } \\
\text { replication } \\
\text { assay, MTT } \\
\text { assay( cell } \\
\text { based assay } \\
\text { protease } \\
\text { inhibition } \\
\text { assay) }\end{array}$ & ND & $\begin{array}{l}\text { In DBM fraction, Inhibitory } \\
\text { cytopathogenic effect at } 25 \\
\text { to } 200 \mu \mathrm{g} / \mathrm{ml} \\
\text { Inhibition of Viral replication } \\
\mathrm{EC}_{50}=8.706 \mathrm{~g} / \mathrm{ml} \text { at con } \\
0.1-10 \mu \mathrm{g} / \mathrm{ml} \text { with SI ( }>62 \text { ) } \\
\text { Considerable inhibitory of } \\
\text { SARS-CoV protease activity } \\
\text { at } \mathrm{IC}_{50} \text { value } 44 \pm 2 \mu \mathrm{g} / \mathrm{ml} \text {, } \\
\text { with biological safe for host } \\
\text { cell in concentration } 10 \text { to } \\
500 \mu \mathrm{g} / \mathrm{ml}\end{array}$ & $\begin{array}{l}\text { SARS-CoV } \\
\text { replication } \\
\text { inhibition } \\
\text { shown by } \\
\text { Valinomycin } \\
\text { with SI value } \\
(41.4) \\
\text { Inhibitory } \\
\text { activity against } \\
\text { SARS-CoV } 3 \mathrm{Cl} \\
\text { protease with } \\
\text { IC } \mathrm{C}_{50}=13 \pm 0.7 \\
\mu \mathrm{g} / \mathrm{ml}\end{array}$ & ND & {$[46]$} \\
\hline 30 & Cassia tora & Fabaceae & Seed & Vero E6 cells & $\begin{array}{l}\text { SARS-CoV } \\
\text { 3CL pro }\end{array}$ & $\begin{array}{l}\text { CPE assay, cell } \\
\text { proliferation } \\
\text { assay,viral } \\
\text { replication } \\
\text { assay, MTT } \\
\text { assay, cell } \\
\text { based assay), } \\
\text { protease } \\
\text { inhibition assay }\end{array}$ & ND & $\begin{array}{l}\text { In CTH fraction, Inhibitory } \\
\text { cytopathogenic effect at } 25 \\
\text { to } 200 \mu \mathrm{g} / \mathrm{ml} \\
\text { Inhibition of Viral replication } \\
\mathrm{EC}_{50}=8.70 \mu \mathrm{g} / \mathrm{ml} \text { at con } 0.1 \text { - } \\
\mu \text { with SI value ( }>59.3 \text { ) } \\
\text { Inhibitory effect on } 3 \mathrm{Cl} \\
\text { protease enzyme with } \\
\mathrm{IC}_{50}(>50 \quad \mu \mathrm{g} / \mathrm{ml}) \text { with } \\
\text { biological safe for host cell } \\
\text { in concentration } 10 \text { to } \\
500 \mu \mathrm{g} / \mathrm{ml}\end{array}$ & $\begin{array}{l}\text { SARS-CoV } \\
\text { replication } \\
\text { inhibition } \\
\text { shown by } \\
\text { Valinomycin } \\
\text { with SI value } \\
(41.4) \\
\text { Inhibitory } \\
\text { activity against } \\
\text { SARS-CoV } 3 \mathrm{Cl} \\
\text { protease with } \\
\text { IC } \mathrm{C}_{50}=13 \pm 0.7 \\
\mu \mathrm{g} / \mathrm{ml}\end{array}$ & ND & {$[46]$} \\
\hline 31 & $\begin{array}{l}\text { Taxillus } \\
\text { chinesis }\end{array}$ & Loranthaceae & $\begin{array}{l}\text { Stem } \\
\text { with } \\
\text { leaves }\end{array}$ & Vero E6 cells & $\begin{array}{l}\text { SARS-CoV } \\
\text { 3CL pro }\end{array}$ & $\begin{array}{l}\text { CPE assay, cell } \\
\text { proliferation } \\
\text { assay, viral } \\
\text { replication } \\
\text { assay, MTT } \\
\text { assay, cell } \\
\text { based assay) } \\
\text { protease } \\
\text { inhibition assay }\end{array}$ & ND & $\begin{array}{l}\text { In } \mathrm{TCH} \text { fraction, Inhibitory } \\
\text { cytopathogenic effect at } 25 \\
\text { to } 200 \mu \mathrm{g} / \mathrm{ml} \\
\text { Inhibition of Viral replication } \\
\mathrm{EC}_{50}=5.3 \mu \mathrm{g} / \mathrm{ml} \text { at con } 0.1 \text { - } \\
10 \mu \mathrm{g} / \mathrm{ml} \text { with SI (>92.8) } \\
\text { Inhibitory effect on } 3 \mathrm{CL} \\
\text { protease enzyme with } \\
\mathrm{IC}_{50}(>50 \mu \mathrm{g} / \mathrm{ml}) \text { with } \\
\text { biological safe for host cell } \\
\text { in concentration } 10 \text { to } \\
500 \mu \mathrm{g} / \mathrm{ml}\end{array}$ & $\begin{array}{l}\text { SARS-CoV } \\
\text { replication } \\
\text { inhibition } \\
\text { shown by } \\
\text { Valinomycin } \\
\text { with SI value } \\
(41.4) \\
\text { Inhibitory } \\
\text { activity against } \\
\text { SARS-CoV } 3 \mathrm{Cl} \\
\text { protease with } \\
\text { IC } \text { C }_{50 \quad 13 \pm 0.7} \\
\mu \mathrm{g} / \mathrm{ml}\end{array}$ & ND & [46] \\
\hline
\end{tabular}




\begin{tabular}{|c|c|c|c|c|c|c|c|c|c|c|c|}
\hline 32 & $\begin{array}{l}\text { Cibotium } \\
\text { barometz }\end{array}$ & Cibotiaceae & Rhizome & Vero E6 cells & $\begin{array}{l}\text { SARS-CoV } \\
3 \mathrm{CL} \text { pro }\end{array}$ & $\begin{array}{l}\text { CPE assay, cell } \\
\text { proliferation } \\
\text { assay,viral } \\
\text { replication } \\
\text { assay, MTT } \\
\text { assay( cell } \\
\text { based assay) } \\
\text { protease } \\
\text { inhibition assay }\end{array}$ & ND & $\begin{array}{l}\text { In CBE /CBM fraction, } \\
\text { Inhibitory of cytopathogenic } \\
\text { effect at } 25 \text { to } 200 \mu \mathrm{g} / \mathrm{ml} \\
\text { SI (>59.4) for } \mathrm{CBE} \text { shows } \\
\text { anti-SARS-CoV activity } \\
\text { IC } 50 \text { ( } 39 \mu \mathrm{g} / \mathrm{ml}) \text { for CBM } \\
\text { shows inhibitory effect } \\
\text { SARS-CoV } 3 \mathrm{CL} \text { Protease } \\
\text { activity, with biological safe } \\
\text { for host cell in concentration } \\
10 \text { to } 500 \mu \mathrm{g} / \mathrm{ml}\end{array}$ & $\begin{array}{l}\text { SARS-CoV } \\
\text { replication } \\
\text { inhibition } \\
\text { shown by } \\
\text { Valinomycin } \\
\text { with SI value } \\
(41.4) \\
\text { Inhibitory } \\
\text { activity against } \\
\text { SARS-CoV } 3 \mathrm{Cl} \\
\text { protease with } \\
\mathrm{IC}=13 \pm 0.7 \\
\mu \mathrm{g} / \mathrm{ml}\end{array}$ & ND & [46] \\
\hline 33 & Toona sinesis & Meliaceae & Leaf & Vero cell line & $\begin{array}{l}\mathrm{HCoV} \\
229 \mathrm{E}\end{array}$ & $\begin{array}{l}\text { Antiviral assay } \\
\text { (CPE ,MTT ) }\end{array}$ & ND & $\begin{array}{l}\text { TSL }-1 \text { show the evident } \\
\text { effect against SARS-CoV } \\
\text { strain with SI value (15) }\end{array}$ & $\begin{array}{l}\text { Actinomycin D } \\
\text { is used as } \\
\text { positive control }\end{array}$ & $\begin{array}{lr}\begin{array}{l}\text { Tender } \\
\text { extract }\end{array} & \text { leaf } \\
\text { Toona } & \text { sinesis } \\
\text { roem } & \text { can } \\
\text { inhibit SARS- } & \text { CoV in vitro }\end{array}$ & [47] \\
\hline 34 & $\begin{array}{l}\text { Camellia } \\
\text { japonica }\end{array}$ & Theaceae & Flower & Vero cell & PEDV & $\begin{array}{l}\text { Cytotoxicity } \\
\text { assay, CPE } \\
\text { assay, }\end{array}$ & $\begin{array}{l}\text { Oleane triterpene } \quad\left(\mathrm{R}^{\prime}=\mathrm{H}\right. \\
\left., \mathrm{R}^{\wedge} 2=\mathrm{CH} 2 \mathrm{OH}\right) \text { ketone group } \\
\text { at } \mathrm{C}-16 \text { and hydroxymethyl } \\
\text { group at } \mathrm{C}-17 \text { position }\end{array}$ & $\begin{array}{l}\text { SI }(44.54 \pm 8.34) \text { showed } \\
\text { potent inhibitory effect on } \\
\text { PEDV replication }\end{array}$ & $\begin{array}{l}\text { Inhibitory effect } \\
\text { of Azauridine } \\
\text { on PEDV } \\
\text { replication with } \\
\text { SI } \quad \text { value } \\
(14.30 \pm 1.24)\end{array}$ & $\begin{array}{l}\text { May be by } \\
\text { reducing the } \\
\text { RNA level } \\
\text { associated with } \\
\text { GP6 } \\
\text { nucleocapsid } \\
\text { GP2 spike and } \\
\text { GPS protein } \\
\text { responsible for } \\
\text { PEDV } \\
\text { replication }\end{array}$ & [48] \\
\hline 35 & $\begin{array}{l}\text { Saposhnikovia } \\
\text { divaricata }\end{array}$ & Apiaceae & Radix & Vero cell & PEDV & $\begin{array}{l}\text { Cytotoxicity } \\
\text { assay, } \mathrm{CPE} \\
\text { assay, }\end{array}$ & $\begin{array}{l}\text { Cis-3-is ovaleryl } \\
\text { acetylkhellactone }\end{array}$ & $\begin{array}{l}\text { SI }(>23.90 \pm 4.11) \text { showed } \\
\text { inhibition effect on PEDV } \\
\text { induced CPE. }\end{array}$ & $\begin{array}{l}\text { Inhibitory effect } \\
\text { of Azauridine } \\
\text { on PEDV } \\
\text { induced CPE } \\
\text { with SI value } \\
9.94 \pm 0.82 \text { ) }\end{array}$ & $\begin{array}{l}\text { Inhibitory } \\
\text { effect on gene } \\
\text { encoding PEDV } \\
\text { GP6 } \\
\text { nucleocapsid } \\
\text { GP2 spike ,GPs } \\
\text { membrane } \\
\text { protein }\end{array}$ & [49] \\
\hline 36 & $\begin{array}{l}\text { Dryoteris } \\
\text { crassirhizoma }\end{array}$ & Dryoptridaceae & Rhizomes & Vero cells & PEDV & $\begin{array}{l}\text { Cytotoxicity } \\
\text { assay, } \mathrm{CPE} \\
\text { assay, }\end{array}$ & $\begin{array}{l}\text { Methylene -bis-methyl } \\
\text { phlorobutyropheone }\end{array}$ & $\begin{array}{l}\text { SI }(39.21 \pm 0.27) \text { showed } \\
\text { potent antiviral effect on } \\
\text { PEDV. }\end{array}$ & $\begin{array}{l}\text { With SI value } \\
\text { for } 6 \text {-azauridine } \\
10.28 \pm 0.54\end{array}$ & $\begin{array}{l}\text { Inhibitory } \\
\text { effect on gene } \\
\text { encoding PEDV } \\
\text { GP6 } \\
\text { nucleocapsid } \\
\text { GP2 spike ,GPs } \\
\text { membrane } \\
\text { protein }\end{array}$ & [49] \\
\hline 37 & $\begin{array}{l}\text { Rheum } \\
\text { palmatum }\end{array}$ & Polygonaceae & Leaves & $\begin{array}{l}E . \\
\text { coliexpression }\end{array}$ & $\begin{array}{l}\text { SARS-CoV } \\
3 \mathrm{CL} \text { pro }\end{array}$ & $\begin{array}{l}\text { inhibition assay } \\
\text { through } \\
\text { determination } \\
\text { of enzyme } \\
\text { velocity } \\
\text { represented by } \\
\text { absorption } \\
\text { assay }\end{array}$ & ND & $\begin{array}{l}\text { Inhibiting the interaction of } \\
\text { SARS-CoV } \mathrm{S} \text { protein and } \\
\text { ACE2 in dose dependent } \\
\text { manner an maximum result } \\
\text { is } 96 \% \text { inhibition with } \\
\mathrm{IC}_{50}=13.76 \pm 0.003 \text { at } \\
100 \mu \mathrm{g} / \mathrm{ml}\end{array}$ & $\begin{array}{l}\text { CHEN-312-5 } \\
\text { showed } \\
\text { inhibitory effect } \\
\text { IC } 50 \text { at } 2.25 \pm \\
0.24 \text { at conc } \\
20 \mu \mathrm{g} / \mathrm{ml} \text { with } \\
\% \text { inhibition } \\
\text { was } 88.3 \pm 2.60 \text {. }\end{array}$ & ND & [50] \\
\hline 38 & $\begin{array}{l}\text { Houttuynia } \\
\text { corda }\end{array}$ & Saururaceae & $\begin{array}{l}\text { Whole } \\
\text { parts }\end{array}$ & $\begin{array}{l}\text { Mouse } \\
\text { splenic } \\
\text { lymphocyte }\end{array}$ & $\begin{array}{l}\text { SARS-CoV } \\
3 \mathrm{CL} \text { pro }\end{array}$ & $\begin{array}{l}\text { protein based } \\
\text { fluorescence } \\
\text { assay,ELISA }\end{array}$ & ND & $\begin{array}{l}\text { Extract shows inhibiting } \\
\text { effect in decrease in } \\
\text { fluorescein ratio of the } \\
\text { substrate implying that it } \\
\text { could inactivate the SARS- } \\
\text { CoV } 3 \mathrm{CL} \text { protease enzyme at } \\
\text { con. } 200 \mu \mathrm{g} / \mathrm{ml} \text { and increased } \\
\mathrm{CD} 4+\text { cell after } 48 \mathrm{hr} \text { and } \\
\mathrm{CD} 8+\text { cell after } 24 \mathrm{hr} \text { and IL } \\
-2 \text { after } 72 \mathrm{hr} \text { in dose } \\
\text { dependent manner }\end{array}$ & ND & $\begin{array}{l}\text { By activating } \\
\text { cell mediating } \\
\text { immunity } \\
\text { before the } \\
\text { invasion of } \\
\text { SARS-CoV } \\
\text { Or by slowing } \\
\text { the viral } \\
\text { replication } \\
\text { process by } \\
\text { inhibiting } \\
\text { pivotal enzyme } \\
\text { and trigger } \\
\text { negative } \\
\text { feedback } \\
\text { control in }\end{array}$ & - \\
\hline
\end{tabular}




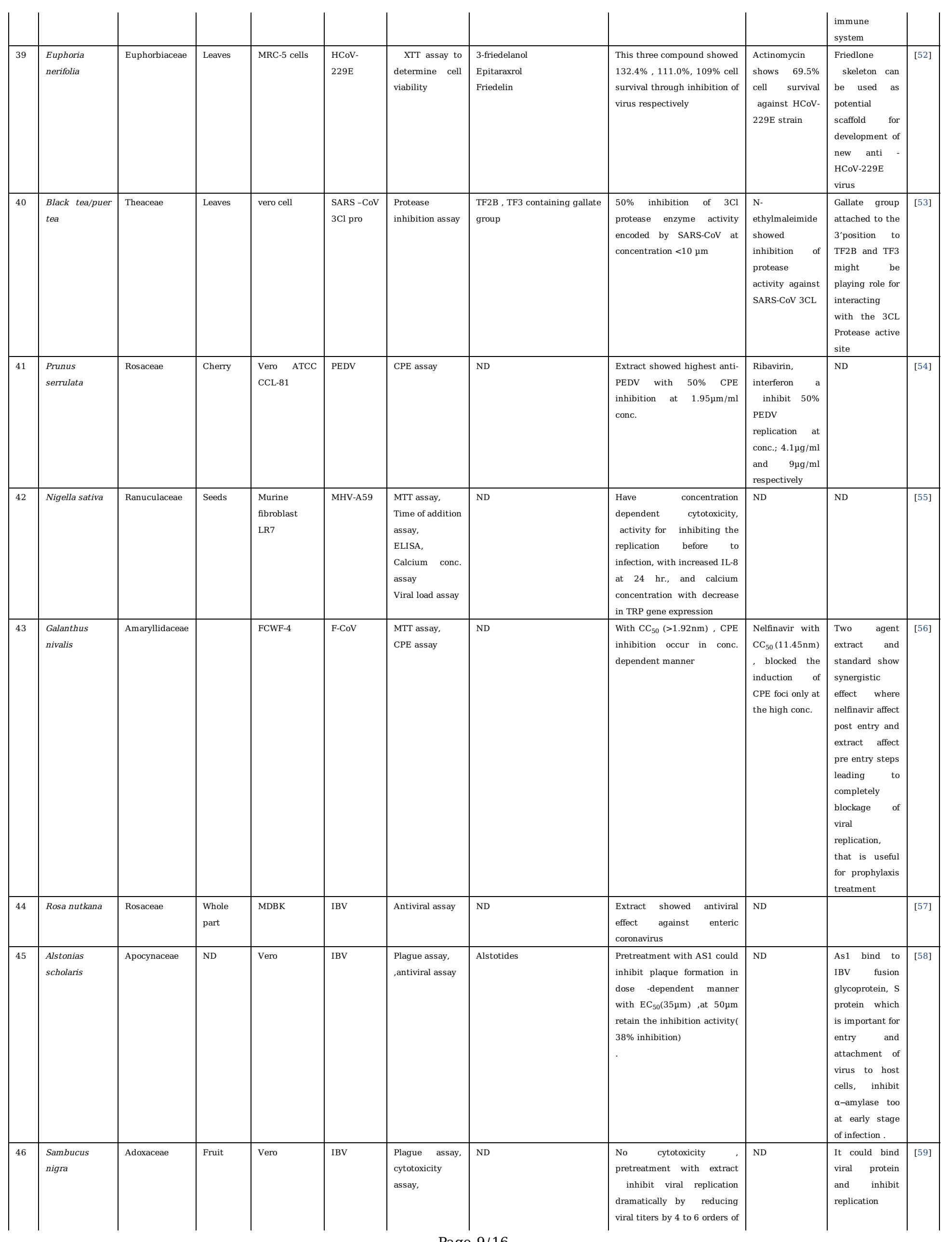

Page 9/16 


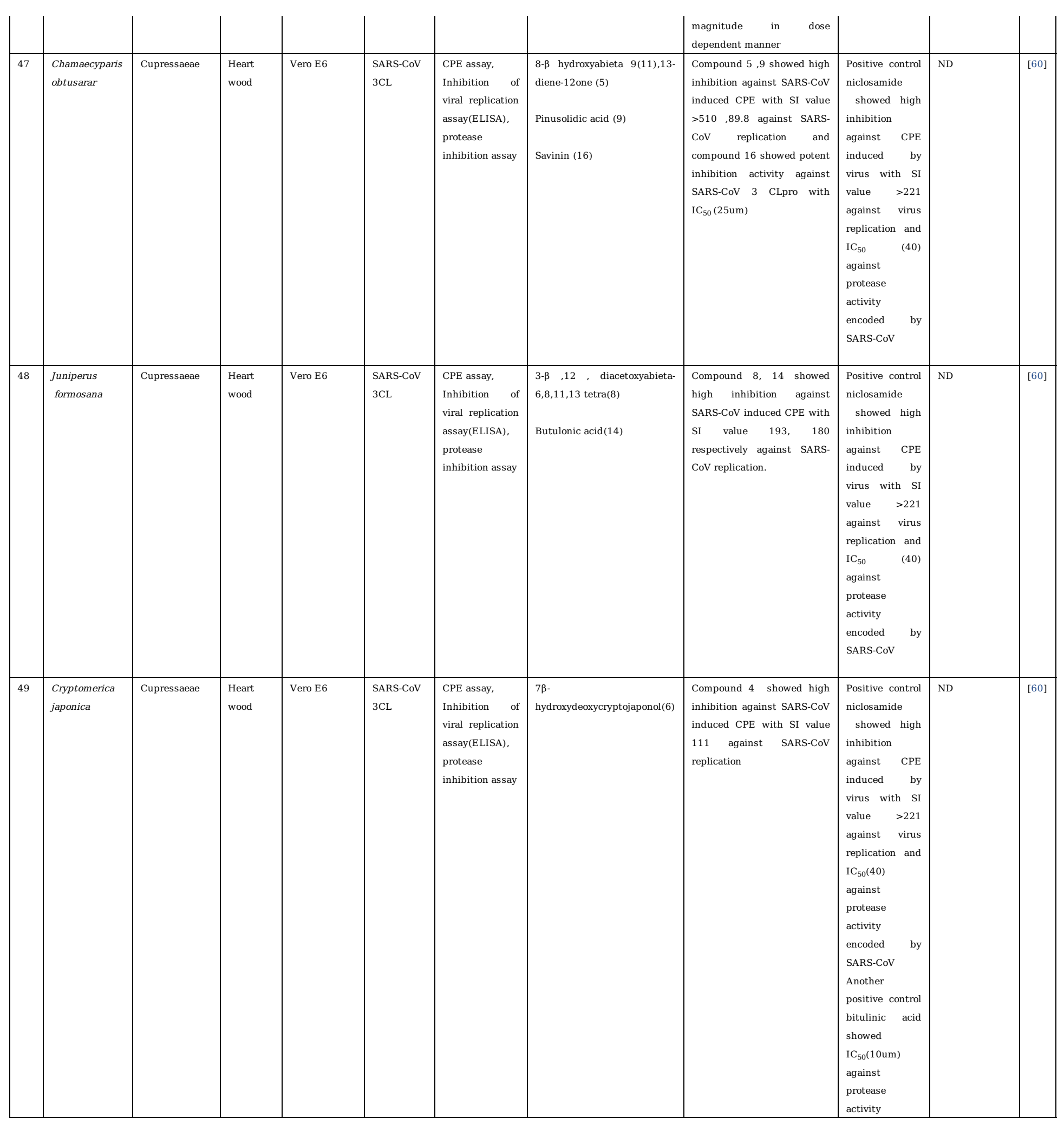

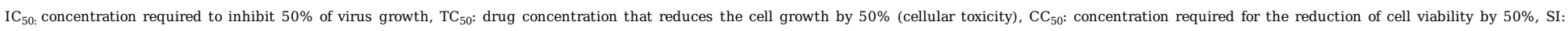
Selectivity Index, ND: Not Defined 


\begin{tabular}{|c|c|c|c|c|c|c|c|c|}
\hline SN & Compound & Source & Culture cell & $\begin{array}{l}\text { Virus( } \\
\text { strain) }\end{array}$ & Method & Result & Conclusion & Reference \\
\hline 1 & $\begin{array}{l}\text { Saikosaponin } \\
\text { B2 }\end{array}$ & $\begin{array}{l}\text { Sigma Chemical } \\
\text { (St Louis, MO, } \\
\text { USA) }\end{array}$ & MRC-5 cell & $\begin{array}{l}\mathrm{HCoV}- \\
229 \mathrm{E}\end{array}$ & $\begin{array}{l}\text { XTT assay, } \\
\text { Attachment } \\
\text { assay/penetration } \\
\text { assay }\end{array}$ & $\begin{array}{l}\text { At concentration } 0.25-25 \mu \mathrm{mol} / \mathrm{l} \text { showed strongest } \\
\text { activity with } \mathrm{EC}_{50}=1.7 \pm 0.1 \mu \mathrm{mol} / \mathrm{l} \text { and } \mathrm{SI}=221.9\end{array}$ & $\begin{array}{l}\text { May be due to interference in the early } \\
\text { stage of viral replication, absorption, and } \\
\text { penetration of the virus }\end{array}$ & [61] \\
\hline 2 & Glycyrrhizin & ND & Vero cells & $\begin{array}{l}\text { FFM-1 } \\
\text { FFM-2 }\end{array}$ & $\begin{array}{l}\text { Viral replication } \\
\text { assay, } \\
\text { cytopathogenicity } \\
\text { assay, cytotoxicity } \\
\text { assay }\end{array}$ & $\begin{array}{l}\text { Most effective when given at early steps of viral } \\
\text { replication and during and after adsorption with SI } \\
=>67 \text {, show potent inhibition of viral replication }\end{array}$ & $\begin{array}{l}\text { May be by affecting cellular signaling } \\
\text { pathway or by inducing production of } \\
\text { nitrous oxide which inhibit viral replication }\end{array}$ & [62] \\
\hline 3 & Tannic acid & $\begin{array}{l}\text { MicroSource } \\
\text { Discovery } \\
\text { Systems, Inc., } \\
\text { Gaylordsville, CT } \\
\end{array}$ & E-coli & $\begin{array}{l}\text { SARS- } \\
\text { CoV } \\
3 \mathrm{Cl} \text { pro }\end{array}$ & $\begin{array}{l}\text { Protease inhibition } \\
\text { assay, flurogenic } \\
\text { substrate peptide } \\
\text { assay }\end{array}$ & $\begin{array}{l}\text { Found to have inhibitory activity against } 3 \mathrm{Cl} \text { pro } \\
\text { encoded by SARS-CoV with } \mathrm{IC}_{50}=3 \mu \mathrm{m}\end{array}$ & $\begin{array}{l}\text { Gallate group may be responsible for } \\
\text { inhibitory activity against target strain }\end{array}$ & [53] \\
\hline 4 & $\begin{array}{l}\text { 3-isotheaflavin- } \\
\text { 3-gallate(TF2B) }\end{array}$ & $\begin{array}{l}\text { MicroSource } \\
\text { Discovery } \\
\text { Systems, Inc., } \\
\text { Gaylordsville, CT } \\
\end{array}$ & E-coli & $\begin{array}{l}\text { SARS- } \\
\text { CoV } \\
3 \mathrm{Cl} \text { pro }\end{array}$ & $\begin{array}{l}\text { Protease inhibition } \\
\text { assay, flurogenic } \\
\text { substrate peptide } \\
\text { assay }\end{array}$ & $\begin{array}{l}\text { Found to have inhibitory activity against } 3 \mathrm{Cl} \text { pro } \\
\text { encoded by SARS-CoV with } \mathrm{IC}_{50}=7 \mu \mathrm{m}\end{array}$ & $\begin{array}{l}\text { Gallate group may be responsible for } \\
\text { inhibitory activity against target strain }\end{array}$ & [53] \\
\hline j & $\begin{array}{l}\text { Theaflavin }-3 ', 3^{\prime}- \\
\text { digallate (TF3) }\end{array}$ & $\begin{array}{l}\text { MicroSource } \\
\text { Discovery } \\
\text { Systems, Inc., } \\
\text { Gaylordsville, CT } \\
\end{array}$ & E-coli & $\begin{array}{l}\text { SARS- } \\
\text { CoV } \\
3 \mathrm{Cl} \text { pro }\end{array}$ & $\begin{array}{l}\text { Protease inhibition } \\
\text { assay, flurogenic } \\
\text { substrate peptide } \\
\text { assay }\end{array}$ & $\begin{array}{l}\text { Found to have inhibitory activity against } 3 \mathrm{CL} \text { pro } \\
\text { encoded by SARS-CoV with } \mathrm{IC}_{50}=9.5 \mu \mathrm{m}\end{array}$ & $\begin{array}{l}\text { Gallate group may be responsible for } \\
\text { inhibitory activity against target strain }\end{array}$ & [53] \\
\hline 5 & Myricetin & Chromadex & MCF10A & $\begin{array}{l}\text { SARS } \\
\text { helicase } \\
\text {,nsp13 }\end{array}$ & $\begin{array}{l}\text { FRET DS ,DNA } \\
\text { unwinding assay } \\
\text { ATP hydrolysis } \\
\text { assay }\end{array}$ & $\begin{array}{l}\text { Inhibit the ATP ase activity of nsp } 13 \text { by more the } 90 \% \\
\text { at concentration } 10 \mu \mathrm{m}\end{array}$ & $\begin{array}{l}\text { By interfering with ATP/ADP binding } \\
\text { pocket of the SARS- CoV helicase protein }\end{array}$ & [63] \\
\hline 7 & Scutellarein & $\begin{array}{l}\text { Scutettaria } \\
\text { baicalensis }\end{array}$ & MCF10A & $\begin{array}{l}\text { SARS } \\
\text { helicase } \\
\text {,nsp13 }\end{array}$ & $\begin{array}{l}\text { FRET DS ,DNA } \\
\text { unwinding assay } \\
\text { ATP hydrolysis } \\
\text { assay }\end{array}$ & Inhibit SARS CoV helicase with $\mathrm{IC}_{50}=0.8 \pm 0.19 \mu \mathrm{m}$ & $\begin{array}{l}\text { By interfering with ATPase activity of the } \\
\text { SARS CoV helicase protein }\end{array}$ & [63] \\
\hline 3 & Tetrandrine & $\begin{array}{l}\text { Wuhan } \\
\text { ChemFaces } \\
\text { Biochemical Co., } \\
\text { Ltd. (Wuhan, } \\
\text { China) }\end{array}$ & $\begin{array}{l}\text { MRC-5 human lung } \\
\text { cells }\end{array}$ & $\begin{array}{l}\mathrm{HCoV}- \\
\mathrm{OC} 43\end{array}$ & $\begin{array}{l}\text { CPE/MTS assay } \\
\text { Time addition } \\
\text { assay } \\
\text { Replication } \\
\text { inhibition assay }\end{array}$ & $\begin{array}{l}\text { Anti } \mathrm{HCoV}-\mathrm{OC} 43 \text { in dose and time dependent manner } \\
\text { with SI>40 with } \mathrm{IC}_{50}=0.33 \pm 0.03\end{array}$ & $\begin{array}{l}\text { Inhibit virus induced cell death at the } \\
\text { early stage of virus infection an suppressed } \\
\text { the replication of virus and inhibited viral } \\
\mathrm{S} \text { and } \mathrm{N} \text { protein expression }\end{array}$ & [64] \\
\hline 9 & Fangchinoline & $\begin{array}{l}\text { Wuhan } \\
\text { ChemFaces } \\
\text { Biochemical Co., } \\
\text { Ltd. (Wuhan, } \\
\text { China) }\end{array}$ & $\begin{array}{l}\text { MRC-5 human lung } \\
\text { cells }\end{array}$ & $\begin{array}{l}\mathrm{HCoV}- \\
\mathrm{OC} 43\end{array}$ & $\begin{array}{l}\text { CPE/MTS assay } \\
\text { Time addition } \\
\text { assay } \\
\text { Replication } \\
\text { inhibition assay } \\
\end{array}$ & $\begin{array}{l}\text { Anti } \mathrm{HCoV}-\mathrm{OC} 43 \text { in dose and time dependent manner } \\
\text { with SI>11 with } \mathrm{IC}_{50}=1.01 \pm 0.07 \mu \mathrm{m}\end{array}$ & $\begin{array}{l}\text { Inhibit virus induced cell death at the } \\
\text { early stage of virus infection an suppressed } \\
\text { the replication of virus and inhibited viral } \\
\mathrm{S} \text { and } \mathrm{N} \text { protein expression }\end{array}$ & [64] \\
\hline 10 & Cepharanthine & $\begin{array}{l}\text { Wuhan Chem } \\
\text { Faces } \\
\text { Biochemical Co., } \\
\text { Ltd. (Wuhan, } \\
\text { China) } \\
\end{array}$ & $\begin{array}{l}\text { MRC-5 human lung } \\
\text { cells }\end{array}$ & $\begin{array}{l}\mathrm{HCoV}- \\
\mathrm{OC} 43\end{array}$ & $\begin{array}{l}\text { CPE/MTS assay } \\
\text { Time addition } \\
\text { assay } \\
\text { Replication } \\
\text { inhibition assay } \\
\end{array}$ & $\begin{array}{l}\text { Anti } \mathrm{HCoV}-\mathrm{OC} 43 \text { in dose and time dependent manner } \\
\text { with SI }>13 \text { with } \mathrm{IC}_{50}=0.83 \pm 0.07 \mu \mathrm{m}\end{array}$ & $\begin{array}{l}\text { Inhibit virus induced cell death at the } \\
\text { early stage of virus infection an suppressed } \\
\text { the replication of virus and inhibited viral } \\
\mathrm{S} \text { and } \mathrm{N} \text { protein expression }\end{array}$ & [64] \\
\hline 11 & Quercetin & Sigma-Aldrich & $\begin{array}{l}\text { Picia pastoris GS } \\
11\end{array}$ & $\begin{array}{l}\text { 3CL pro } \\
\text { SARS- } \\
\text { CoV }\end{array}$ & $\begin{array}{l}\text { FRET inhibition } \\
\text { assay } \\
\text { Docking analysis }\end{array}$ & $\begin{array}{l}82 \% \text { inhibition of SARS-CoV 3CL pro activity with } \mathrm{IC}_{50} \\
=73 \pm_{4 \mu \mathrm{m}}\end{array}$ & $\begin{array}{l}\text { numerous hydrophobic and H-bonds } \\
\text { interaction with amino acid residues in the } \\
\text { active site pocket of } 3 \mathrm{CL} \text { pro and inhibiting } \\
\text { the activity. }\end{array}$ & [65] \\
\hline 12 & $\begin{array}{l}\text { Epigallocatechin } \\
\text { gallate }\end{array}$ & Sigma-Aldrich & $\begin{array}{l}\text { Picia pastoris GS } \\
11\end{array}$ & $\begin{array}{l}\text { 3CL pro } \\
\text { SARS- } \\
\text { CoV }\end{array}$ & $\begin{array}{l}\text { FRET inhibition } \\
\text { assay } \\
\text { Docking analysis }\end{array}$ & $\begin{array}{l}85 \% \text { inhibition of SARS-CoV } 3 \mathrm{Cl} \text { pro activity with } \\
\mathrm{IC}_{50}=73 \pm 2 \mu \mathrm{m}\end{array}$ & $\begin{array}{l}\text { Numerous hydrophobic and H-bonds } \\
\text { interaction with amino acid residues in the } \\
\text { active site pocket of } 3 \mathrm{CL} \text { pro and inhibiting } \\
\text { the activity. }\end{array}$ & [65] \\
\hline 13 & $\begin{array}{l}\text { Gallocatechin } \\
\text { gallate }\end{array}$ & Sigma-Aldrich & $\begin{array}{l}\text { Picia pastoris GS } \\
11\end{array}$ & $\begin{array}{l}\text { 3CL pro } \\
\text { SARS- } \\
\text { CoV }\end{array}$ & $\begin{array}{l}\text { FRET inhibition } \\
\text { assay } \\
\text { Docking analysis }\end{array}$ & $\begin{array}{l}91 \% \text { inhibition of SARS } 3 \mathrm{CL} \text { pro activity with } \\
\mathrm{IC}_{50}=47 \pm 0.9\end{array}$ & $\begin{array}{l}\text { Numerous hydrophobic and H-bonds } \\
\text { interaction with amino acid residues in the } \\
\text { active site pocket of } 3 \text { CL pro and inhibiting } \\
\text { the activity }\end{array}$ & [65] \\
\hline 14 & Herbacetin & ND & ND & $\begin{array}{l}\text { 3CL Pro } \\
\text { MERS- } \\
\text { CoV }\end{array}$ & $\begin{array}{l}\text { Antiviral assay, } \\
\text { tryptophan based } \\
\text { FRET assay, } \\
\text { Docking analysis } \\
\end{array}$ & $\begin{array}{l}\text { Block enzymatic activity of MERS }-\mathrm{CoV} 3 \mathrm{Cl} \text { pro with } \\
\mathrm{IC}_{50} 40.59 \mu \mathrm{m}\end{array}$ & $\begin{array}{l}\text { inhibition of main viral proteases and thus } \\
\text { nullify a process of virus peptides }\end{array}$ & {$[66]$} \\
\hline 15 & Isobavachalcole & ND & ND & $\begin{array}{l}\text { 3Cl Pro } \\
\text { MERS- } \\
\text { CoV }\end{array}$ & $\begin{array}{l}\text { Antiviral assay, } \\
\text { tryptophan based } \\
\text { FRET assay, } \\
\text { Docking analysis }\end{array}$ & $\begin{array}{l}\text { Block enzymatic activity of MERS }-\mathrm{CoV} 3 \mathrm{Cl} \text { pro with } \\
\mathrm{IC}_{50} 35.85 \mu \mathrm{m}\end{array}$ & $\begin{array}{l}\text { inhibition of main viral proteases and thus } \\
\text { nullify a process of virus peptides }\end{array}$ & {$[66]$} \\
\hline 16 & $\begin{array}{l}\text { Quercetin -3-B-d } \\
\text { glucoside }\end{array}$ & ND & ND & $\begin{array}{l}\text { 3Cl Pro } \\
\text { MERS- } \\
\text { CoV }\end{array}$ & $\begin{array}{l}\text { Antiviral assay, } \\
\text { tryptophan based } \\
\text { FRET assay, } \\
\text { Docking analysis }\end{array}$ & $\begin{array}{l}\text { Block enzymatic activity of MERS }-\mathrm{CoV} 3 \mathrm{Cl} \text { pro with } \\
\mathrm{IC}_{50} 37.03 \mu \mathrm{m}\end{array}$ & $\begin{array}{l}\text { inhibition of main viral proteases and thus } \\
\text { nullify a process of virus peptides }\end{array}$ & {$[66]$} \\
\hline 17 & Helichrysetin & ND & ND & $\begin{array}{l}3 \mathrm{Cl} \text { Pro } \\
\text { MERS- } \\
\mathrm{CoV}\end{array}$ & $\begin{array}{l}\text { Antiviral assay, } \\
\text { tryptophan } \quad \text { based }\end{array}$ & $\begin{array}{l}\text { Block enzymatic activity of MERS }-\mathrm{CoV} 3 \mathrm{Cl} \text { pro with } \\
\mathrm{IC}_{50} 67.0 \text { s } \mu \mathrm{m}\end{array}$ & $\begin{array}{l}\text { inhibition of main viral proteases and thus } \\
\text { nullify a process of virus peptides }\end{array}$ & {$[66]$} \\
\hline
\end{tabular}




\begin{tabular}{|c|c|c|c|c|c|c|c|c|}
\hline & & & & & $\begin{array}{l}\text { FRET assay, } \\
\text { Docking analysis }\end{array}$ & & & \\
\hline 18 & $\begin{array}{l}\text { Kaemferol } \\
\text { derivatives } \\
\text { (Juglanin } \\
\text { glycoside) }\end{array}$ & Viola odorata L & Xenopus oocyte & $\begin{array}{l}\text { 3a } \\
\text { protein } \\
\text { of } \\
\text { SARS- } \\
\text { CoV }\end{array}$ & $\begin{array}{l}\text { Voltage clamp } \\
\text { experiment }\end{array}$ & $\begin{array}{l}\text { At } 20 \mu \mathrm{m}, 10 \mu \mathrm{m} \text { it show complete inhibition of ion } \\
\text { flow through } 3 \mathrm{a} \text { protein with } \mathrm{IC}_{50} 2.3 \mu \mathrm{m} \text { and at } \\
-100 \mathrm{mv} \text { the current was inhibited to } 0.77 \pm 0.08 \text { of } \\
\text { control current in the absence of the drug }\end{array}$ & $\begin{array}{l}\text { May be by blocking 3a channel , } \\
\text { counteracting virus production and } \\
\text { interfering with other steps of viral cycle }\end{array}$ & [67] \\
\hline 19 & Emodin & ND & $\begin{array}{l}\text { Xenopus oocyte, } \\
\text { Rhabdomyosarcoma } \\
\text { cells }\end{array}$ & $\begin{array}{l}\text { HCOV- } \\
\text { a43/ } \\
\text { SARS- } \\
\text { Cov 3a }\end{array}$ & $\begin{array}{l}\text { Volatge clamp } \\
\text { experiment }\end{array}$ & $\begin{array}{l}\text { Inhibit of 3a channel with k1/2 value of about } 20 \mathrm{um} \\
\text { and also inhibit HCoV-OC43 release from infected RD } \\
\text { cells }\end{array}$ & $\begin{array}{l}\text { By inhibition of ion flow through 3a protein } \\
\text { channel in a sense that viral ion channel } \\
\text { may be involved in MOA of viral release } \\
\text { from infected cells }\end{array}$ & [68] \\
\hline
\end{tabular}

In this review, as per the data available on the various parts of the plants and compounds from different articles published, they showed that they possess antiviral activity against coronavirus strains (human coronavirus and non-human coronavirus)in the mild, moderate and strong condition. Through in-vitro tests on various parts of the plant (leaves, flower, aerial parts, rhizomes, and fruit) and different compound bought from the market/pharmaceutical/chemical company. Among various techniques used for the detection of viral inhibition, cytopathic reduction assay was the most common technique for in-vitro analyzation in the antiviral study. We know that medicinal plants are the good sources of various phytochemical compounds that provide the basis for the development of new antiviral agents against different virus strains. The WHO (world health organization) has an estimated $80 \%$ of the world population fulfil their healthcare needs from phytomedicinal sources. The mechanism of the antiviral potential of plant extract or various compounds varies among the different strains of the virus. Some phytochemical compounds target viral envelope, some membrane protein, some of them focus ion channel, some inhibit the virus's attachment to the host cell, and some inhibit CPE (cytopathogenic effect) on host cells/plagues formation or ion concentration intracellularly.

The present review showed that the above mention plant and compound (Table 1 and Table 2) containing bioactive substances have some amount of promising antiviral activity. Among the listed plants, the most prominent and potent effect shown by Allium porum, Urtica dioica, Lycoris radiata, Juniperus formosa and Cryptomerica japonica against SARS-CoV with SI value 222, >77, >900,>180 and >111 respectively as compared with standard mentioned by [69]. Similarly, Sophorae radix was found to have the highest inhibition activity against MHV -A59 coronavirus with SI value 696 compared with other compounds. Plant and for SARS-CoV 3 CL proenzyme Dioscorea batatas showed the most effective reasultCibotium barometz, Cassia tora with SI value $>62,>59.4,>59.3$ respectively.

Calophyllum blancoi , Torilis fructus , Acanthopanacis cortex, Sophorae Radix , Allium purum, Urtica dioica and Nicotiana tobaccum were found to have $50 \%$ maximum potent activity against coronavirus species. At low concentration $3 \mu \mathrm{g} / \mathrm{ml}, 0.8 \mu \mathrm{g} / \mathrm{ml}, 0.9 \pm 0.1 \mu \mathrm{g} / \mathrm{ml}, 0.8 \pm 0.2 \mu \mathrm{g} / \mathrm{ml}, 0.45 \mu \mathrm{g} / \mathrm{ml}$, $1.3 \pm 0.1 \mu \mathrm{g} / \mathrm{ml}$ and $1.7 \pm 0.3 \mu \mathrm{g} / \mathrm{ml}$ respectively which have a comparable result to the standard drug used for the coronavirus strain according to [69]. Taxillus chinesis showed a similar effect with the standard one to inhibit replicating the virus with EC50 5.3 $\mu \mathrm{g} / \mathrm{ml}$. Similarly, plants showing the highest IC50 activity at lower concentrations are Brousnoeti papyrifera (IC50=3.7 $\mu \mathrm{m})$, Paulownia tomentosa (IC50=5-14.4 $\mu \mathrm{m})$, Torreya nucifera $(\mathrm{IC} 50=8.3 \mu \mathrm{g} / \mathrm{ml})$ against SARS-CoV enzyme. Sambus formosana showed the most potent IC50 value activity against plaque formation $(\mathrm{IC} 50=1.75)$ and for virus attachment $(4.67 \mu \mathrm{g} / \mathrm{ml})$ in host cells infected with HCoV-NL63 strain of the virus. Torilis fructus, Acanthopancis cortex showed the highest value for reducing intracellular viral mRNA by $93 \%$ and $90 \%$, respectively. Euphoria nerifolia was showed $>100 \%$ cell survival through inhibition of virus activity against coronavirus when compared with standard.

A compound like Saikosaponin B2 was found to have maximum effective against Human coronavirus in a dose-dependent and time-dependent manner with SI (221.9) and EC50 $=1.7 \pm 0.1 \mu \mathrm{mol} / \mathrm{I}$, Isobavachalcole against $3 \mathrm{CL}$ pro-MERS CoV with IC50 $(35.8 \mu \mathrm{m})$ and Gallocatechin gallate

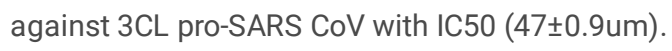

We encountered 49 plants and 19 compound chemically defined natural molecules reported in the literature, which have evaluated for potent antiviral activity against different coronavirus strains. The active compounds, which have been isolated and identified, belong to the classes of alkaloids, terpenoids, xanthones,), flavonoids, steroid, lipids, oxygen benzenoids, carbohydrates, lignans, proteins, coumarins, phenylpropanoids, polyphenols,resins, glycosides, etc. These natural metabolites act as a key for antiviral activity.

\section{Methodology}

A search was conducted in the following databases or search engines: PubMed, Science Direct, MedLine, Google Scholar, and Biomed central for published articles. The keyword 'coronavirus' was paired with 'natural products', 'medicinal plants', 'phytochemicals', 'alkaloids', 'glycosides', 'flavonoids', 'saponins', 'terpenes', 'monoterpenes', 'diterpenes', 'sesquiterpenes', 'triterpenes', 'terpenoids', 'tannins', 'saponins', 'phenols', 'polyphenols', 'herbal drugs', 'crude extracts', or 'synthetic derivatives of natural products' to obtain published records till May 2020. No language restriction was imposed. Obtained records in this study were included and excluded based on the following criteria. The inclusion data criteria included

1. Studies involving crude extract, fraction, or their preparation of plants acting against CoV strains.

Page 12/16 
2. Studies related to derivatives of natural products (e.g., isolated compounds) and chemicals or biochemicals acting against CoV strains.

3. Studies with natural product inspired synthetic derivatives acting against CoV strains.

The exclusion data criteria included: (a) Data duplication and titles or contents that do not meet the inclusion criteria, (b) Reports on antiviral activities of natural products or their derivatives against other than CoV strains.

\section{Conclusion}

Natural products provide a valuable and authoritative resource of chemical compounds displaying antiviral properties. Structure modification of these compounds may help in improving and increasing their potency. The development of antiviral drugs is a challenge, and some antiviral medications can only prevent virus replication or inhibit further infection. In this review, different methods and its possible mechanism showing antiviral property have been highlighted. In the present situation, there is no proper development of antiviral drugs due to which the world is searching for its remedies in nature. All the listed plants and their compounds in this review are highly potent with promising results against coronavirus. These can be further screened for invasive tests and used for making different formulations or may be polyherbal formulations considering its safety profile and toxicity.

\section{Declarations}

Author contribution: conceptualization, writing, , referencing, Sindhu KC, Conceptualization, referencing, writing, supervision, Draft preparation, Manoj Pandit, writing, reviewing, editing, Amit Kumar Shrivastava

Conflict of interest: the author declares no conflict of interest

\section{References}

1. Bárcena M, Oostergetel GT, Bartelink W, Faas FG, Verkleij A, Rottier PJ, Koster AJ, Bosch BJ: Cryo-electron tomography of mouse hepatitis virus: insights into the structure of the coronavirion. Proceedings of the National Academy of Sciences 2009, 106(2):582-587.

2. Zhao L, Jha BK, Wu A, Elliott R, Ziebuhr J, Gorbalenya AE, Silverman RH, Weiss SR: Antagonism of the interferon-induced OAS-RNase L pathway by murine coronavirus ns2 protein is required for virus replication and liver pathology. Cell host \& microbe 2012, 11(6):607-616.

3. Delmas B, Laude H: Assembly of coronavirus spike protein into trimers and its role in epitope expression. Journal of virology 1990 , 64(11):5367-5375.

4. Beniac DR, Devarennes SL, Andonov A, He R, Booth TF: Conformational reorganization of the SARS coronavirus spike following receptor binding: implications for membrane fusion. PLoS One 2007, 2(10):e1082.

5. Bosch BJ, Van der Zee R, De Haan CA, Rottier PJ: The coronavirus spike protein is a class I virus fusion protein: structural and functional characterization of the fusion core complex. Journal of virology 2003, 77(16):8801-8811.

6. Raj VS, Mou H, Smits SL, Dekkers DH, Müller MA, Dijkman R, Muth D, Demmers JA, Zaki A, Fouchier RA: Dipeptidyl peptidase 4 is a functional receptor for the emerging human coronavirus-EMC. Nature 2013, 495(7440):251-254.

7. Yeager CL, Ashmun RA, Williams RK, Cardellichio CB, Shapiro LH, Look AT, Holmes KV: Human aminopeptidase N is a receptor for human coronavirus 229E. Nature 1992, 357(6377):420-422.

8. Nédellec P, Dveksler GS, Daniels E, Turbide C, Chow B, Basile AA, Holmes KV, Beauchemin N: Bgp2, a new member of the carcinoembryonic antigen-related gene family, encodes an alternative receptor for mouse hepatitis viruses. Journal of virology 1994, 68(7):4525-4537.

9. Williams RK, Jiang G-S, Holmes KV: Receptor for mouse hepatitis virus is a member of the carcinoembryonic antigen family of glycoproteins. Proceedings of the National Academy of Sciences 1991, 88(13):5533-5536.

10. Li W, Moore MJ, Vasilieva N, Sui J, Wong SK, Berne MA, Somasundaran M, Sullivan JL, Luzuriaga K, Greenough TC: Angiotensin-converting enzyme 2 is a functional receptor for the SARS coronavirus. Nature 2003, 426(6965):450-454.

11. Chen Y, Liu Q, Guo D: Emerging coronaviruses: genome structure, replication, and pathogenesis. Journal of medical virology 2020, 92(4):418423.

12. Monto AS: Medical reviews. Coronaviruses. The Yale journal of biology and medicine 1974, 47(4):234.

13. Bastien N, Anderson K, Hart L, Caeseele PV, Brandt K, Milley D, Hatchette III T, Weiss EC, Li Y: Human coronavirus NL63 infection in Canada. The Journal of infectious diseases 2005, 191(4):503-506.

14. Hung LS: The SARS epidemic in Hong Kong: what lessons have we learned? Journal of the Royal Society of Medicine 2003, 96(8):374-378.

15. Bleibtreu A, Bertine M, Bertin C, Houhou-Fidouh N, Visseaux B: Focus on Middle East respiratory syndrome coronavirus (MERS-CoV). Medecine et maladies infectieuses 2019.

16. Mole B: Deadly pig virus slips through US borders. Nature 2013, 499(7459):388. 
17. Cui J, Li F, Shi Z-L: Origin and evolution of pathogenic coronaviruses. Nature Reviews Microbiology 2019, 17(3):181-192.

18. Lai C-C, Shih T-P, Ko W-C, Tang H-J, Hsueh P-R: Severe acute respiratory syndrome coronavirus 2 (SARS-CoV-2) and corona virus disease-2019 (COVID-19): the epidemic and the challenges. International journal of antimicrobial agents 2020:105924.

19. Shereen MA, Khan S, Kazmi A, Bashir N, Siddique R: COVID-19 infection: Origin, transmission, and characteristics of human coronaviruses. Journal of Advanced Research 2020.

20. Zhao Z, Li H, Wu X, Zhong Y, Zhang K, Zhang Y-P, Boerwinkle E, Fu Y-X: Moderate mutation rate in the SARS coronavirus genome and its implications. BMC evolutionary biology 2004, 4(1):21.

21. VR S: In vitro antibacterial activity of Clove and Pepper on Streptococcus mutans. IN VITRO 2015, 8(5).

22. Rates SMK: Plants as source of drugs. Toxicon 2001, 39(5):603-613.

23. Jennifer C, Stephie C, Abhishri S, Shalini B: A review on skin whitening property of plant extracts. International Journal of Pharma and Bio Sciences 2012, 3(4):332-347.

24. Sharma RA, Kumari A: Phytochemistry, pharmacology and therapeutic application of oxalis corniculata linn.-a review. Int J Pharm Pharm Sci 2014, 3:6-12.

25. Tyagi S: Phytochemical standardization of Diploknema butyracea (Roxb.) HJ Lam. seeds by HPTLC technique. Indian Journal of Natural Products and Resources (IJNPR) [Formerly Natural Product Radiance (NPR)] 2015, 6(4):299-304.

26. Cseke LJ, Kirakosyan A, Kaufman PB, Warber S, Duke JA, Brielmann HL: Natural products from plants: CRC press; 2016.

27. Gandhi GR, Barreto PG, dos Santos Lima B, Quintans JdSS, de Souza Araujo AA, Narain N, Quintans-Junior LJ, Gurgel RQ: Medicinal plants and natural molecules with in vitro and in vivo activity against rotavirus: A systematic review. Phytomedicine 2016, 23(14):1830-1842.

28. Jaime MFV, Redko F, Muschietti LV, Campos RH, Martino VS, Cavallaro LV: In vitro antiviral activity of plant extracts from Asteraceae medicinal plants. Virology journal 2013, 10(1):245.

29. Kaškonienė V, Stankevičius M, Drevinskas T, Akuneca I, Kaškonas P, Bimbiraitè-Survilienė K, Maruška A, Ragažinskienė O, Kornyšova O, Briedis V: Evaluation of phytochemical composition of fresh and dried raw material of introduced Chamerion angustifolium L. using chromatographic, spectrophotometric and chemometric techniques. Phytochemistry 2015, 115:184-193.

30. Tripathi A, Sinha S, Dwivedi BK: An Attempt to Evaluate Antiviral Activity of Plant Extracts to Combat Infections Caused by Viruses Including SARS COV-2. Available at SSRN 35994442020.

31. Chattopadhyay D, Khan MTH: Ethnomedicines and ethnomedicinal phytophores against herpesviruses. Biotechnology annual review 2008, 14:297-348.

32. Chattopadhyay D, Naik TN: Antivirals of ethnomedicinal origin: structure-activity relationship and scope. Mini reviews in medicinal chemistry 2007, 7(3):275-301.

33. Pandey M, Debnath M, Gupta S, Chikara SK: Phytomedicine: An ancient approach turning into future potential source of therapeutics. Journal of Pharmacognosy and phytotherapy 2011, 3(1):113-117.

34. Keyaerts E, Vijgen L, Pannecouque C, Van Damme E, Peumans W, Egberink H, Balzarini J, Van Ranst M: Plant lectins are potent inhibitors of coronaviruses by interfering with two targets in the viral replication cycle. Antiviral research 2007, 75(3):179-187.

35. Loizzo MR, Saab AM, Tundis R, Statti GA, Menichini F, Lampronti I, Gambari R, Cinatl J, Doerr HW: Phytochemical analysis and in vitro antiviral activities of the essential oils of seven Lebanon species. Chemistry \& biodiversity 2008, 5(3):461-470.

36. Shen Y-C, Wang L-T, Khalil AT, Chiang LC, Cheng P-W: Bioactive pyranoxanthones from the roots of Calophyllum blancoi. Chemical and pharmaceutical bulletin 2005, 53(2):244-247.

37. Park J-Y, Yuk HJ, Ryu HW, Lim SH, Kim KS, Park KH, Ryu YB, Lee WS: Evaluation of polyphenols from Broussonetia papyrifera as coronavirus protease inhibitors. Journal of enzyme inhibition and medicinal chemistry 2017, 32(1):504-512.

38. Cho JK, Curtis-Long MJ, Lee KH, Kim DW, Ryu HW, Yuk HJ, Park KH: Geranylated flavonoids displaying SARS-CoV papain-like protease inhibition from the fruits of Paulownia tomentosa. Bioorganic \& medicinal chemistry 2013, 21(11):3051-3057.

39. Kim DW, Seo KH, Curtis-Long MJ, Oh KY, Oh J-W, Cho JK, Lee KH, Park KH: Phenolic phytochemical displaying SARS-CoV papain-like protease inhibition from the seeds of Psoralea corylifolia. Journal of enzyme inhibition and medicinal chemistry 2014, 29(1):59-63.

40. Weng J-R, Lin C-S, Lai H-C, Lin Y-P, Wang C-Y, Tsai Y-C, Wu K-C, Huang S-H, Lin C-W: Antiviral activity of Sambucus FormosanaNakai ethanol extract and related phenolic acid constituents against human coronavirus NL63. Virus research 2019, 273:197767.

41. Li S-y, Chen C, Zhang H-q, Guo H-y, Wang H, Wang L, Zhang X, Hua S-n, Yu J, Xiao P-g: Identification of natural compounds with antiviral activities against SARS-associated coronavirus. Antiviral research 2005, 67(1):18-23.

42. Lin C-W, Tsai F-J, Tsai C-H, Lai C-C, Wan L, Ho T-Y, Hsieh C-C, Chao P-DL: Anti-SARS coronavirus 3C-like protease effects of Isatis indigotica root and plant-derived phenolic compounds. Antiviral research 2005, 68(1):36-42.

43. Ryu YB, Jeong HJ, Kim JH, Kim YM, Park J-Y, Kim D, Naguyen TTH, Park S-J, Chang JS, Park KH: Biflavonoids from Torreya nucifera displaying SARS-CoV 3CLpro inhibition. Bioorganic \& medicinal chemistry 2010, 18(22):7940-7947. 
44. Kim H-Y, Shin H-S, Park H, Kim Y-C, Yun YG, Park S, Shin H-J, Kim K: In vitro inhibition of coronavirus replications by the traditionally used medicinal herbal extracts, Cimicifuga rhizoma, Meliae cortex, Coptidis rhizoma, and Phellodendron cortex. Journal of clinical virology 2008, 41(2):122-128.

45. Kim H-Y, Eo E-Y, Park H, Kim Y-C, Park S, Shin H-J, Kim K: Medicinal herbal extracts of Sophorae radix, Acanthopanacis cortex, Sanguisorbae radix and Torilis fructus inhibit coronavirus replication in vitro. Antivir Ther 2010, 15(5):697-709.

46. Wen C-C, Shyur L-F, Jan J-T, Liang P-H, Kuo C-J, Arulselvan P, Wu J-B, Kuo S-C, Yang N-S: Traditional Chinese medicine herbal extracts of Cibotium barometz, Gentiana scabra, Dioscorea batatas, Cassia tora, and Taxillus chinensis inhibit SARS-CoV replication. Journal of traditional and complementary medicine 2011, 1(1):41-50.

47. Chen C-J, Michaelis M, Hsu H-K, Tsai C-C, Yang KD, Wu Y-C, Cinatl Jr J, Doerr HW: Toona sinensis Roem tender leaf extract inhibits SARS coronavirus replication. Journal of ethnopharmacology 2008, 120(1):108-111.

48. Yang J-L, Ha T-K-Q, Dhodary B, Pyo E, Nguyen NH, Cho H, Kim E, Oh WK: Oleanane triterpenes from the flowers of Camellia japonica inhibit porcine epidemic diarrhea virus (PEDV) replication. Journal of Medicinal Chemistry 2015, 58(3):1268-1280.

49. Yang J-L, Ha TKQ, Oh WK: Discovery of inhibitory materials against PEDV corona virus from medicinal plants. Japanese Journal of Veterinary Research 2016, 64(Supplement 1):S53-S63.

50. Luo W, Su X, Gong S, Qin Y, Liu W, Li J, Yu H, Xu Q: Anti-SARS coronavirus 3C-like protease effects of Rheum palmatum L. extracts. Bioscience trends 2009, 3(4).

51. Lau K-M, Lee K-M, Koon C-M, Cheung CS-F, Lau C-P, Ho H-M, Lee MY-H, Au SW-N, Cheng CH-K, Bik-San Lau C: Immunomodulatory and antiSARS activities of Houttuynia cordata. Journal of Ethnopharmacology 2008, 118(1):79-85.

52. Chang F-R, Yen C-T, Ei-Shazly M, Lin W-H, Yen M-H, Lin K-H, Wu Y-C: Anti-human coronavirus (anti-HCoV) triterpenoids from the leaves of Euphorbia neriifolia. Natural product communications 2012, 7(11):1934578X1200701103.

53. Chen C-N, Lin CP, Huang K-K, Chen W-C, Hsieh H-P, Liang P-H, Hsu JT-A: Inhibition of SARS-CoV 3C-like protease activity by theaflavin-3, 3'digallate (TF3). Evidence-Based Complementary and Alternative Medicine 2005, 2.

54. Yook H-S, Kim K-H, Park J-E, Shin H-J: Antioxidative and antiviral properties of flowering cherry fruits (Prunus serrulata L. var. spontanea). The American journal of Chinese medicine 2010, 38(05):937-948.

55. Ulasli M, Gurses SA, Bayraktar R, Yumrutas O, Oztuzcu S, Igci M, Igci YZ, Cakmak EA, Arslan A: The effects of Nigella sativa (Ns), Anthemis hyalina (Ah) and Citrus sinensis (Cs) extracts on the replication of coronavirus and the expression of TRP genes family. Molecular biology reports 2014, 41(3):1703-1711.

56. Hsieh L-E, Lin C-N, Su B-L, Jan T-R, Chen C-M, Wang C-H, Lin D-S, Lin C-T, Chueh L-L: Synergistic antiviral effect of Galanthus nivalis agglutinin and nelfinavir against feline coronavirus. Antiviral research 2010, 88(1):25-30.

57. McCutcheon A, Roberts T, Gibbons E, Ellis S, Babiuk L, Hancock R, Towers G: Antiviral screening of British Columbian medicinal plants. Journal of Ethnopharmacology 1995, 49(2):101-110.

58. Nguyen PQT, Ooi JSG, Nguyen NTK, Wang S, Huang M, Liu DX, Tam JP: Antiviral cystine knot a-amylase inhibitors from Alstonia scholaris. Journal of Biological Chemistry 2015, 290(52):31138-31150.

59. Chen C, Zuckerman DM, Brantley S, Sharpe M, Childress K, Hoiczyk E, Pendleton AR: Sambucus nigra extracts inhibit infectious bronchitis virus at an early point during replication. BMC veterinary research 2014, 10(1):1-12.

60. Wen C-C, Kuo Y-H, Jan J-T, Liang P-H, Wang S-Y, Liu H-G, Lee C-K, Chang S-T, Kuo C-J, Lee S-S: Specific plant terpenoids and lignoids possess potent antiviral activities against severe acute respiratory syndrome coronavirus. Journal of medicinal chemistry 2007, 50(17):4087-4095.

61. Cheng PW, Ng LT, Chiang LC, Lin CC: Antiviral effects of saikosaponins on human coronavirus 229E in vitro. Clinical and Experimental Pharmacology and Physiology 2006, 33(7):612-616.

62. Cinatl J, Morgenstern B, Bauer G, Chandra P, Rabenau H, Doerr H: Glycyrrhizin, an active component of liquorice roots, and replication of SARSassociated coronavirus. The Lancet 2003, 361(9374):2045-2046.

63. Yu M-S, Lee J, Lee JM, Kim Y, Chin Y-W, Jee J-G, Keum Y-S, Jeong Y-J: Identification of myricetin and scutellarein as novel chemical inhibitors of the SARS coronavirus helicase, nsP13. Bioorganic \& medicinal chemistry letters 2012, 22(12):4049-4054.

64. Kim DE, Min JS, Jang MS, Lee JY, Shin YS, Park CM, Song JH, Kim HR, Kim S, Jin Y-H: Natural bis-benzylisoquinoline alkaloids-tetrandrine, fangchinoline, and cepharanthine, inhibit human coronavirus 0C43 infection of MRC-5 human lung cells. Biomolecules 2019, 9(11):696.

65. Nguyen TTH, Woo H-J, Kang H-K, Kim Y-M, Kim D-W, Ahn S-A, Xia Y, Kim D: Flavonoid-mediated inhibition of SARS coronavirus 3C-like protease expressed in Pichia pastoris. Biotechnology letters 2012, 34(5):831-838.

66. Jo S, Kim H, Kim S, Shin DH, Kim MS: Characteristics of flavonoids as potent MERS-CoV 3C-like protease inhibitors. Chemical biology \& drug design 2019, 94(6):2023-2030.

67. Schwarz S, Sauter D, Wang K, Zhang R, Sun B, Karioti A, Bilia AR, Efferth T, Schwarz W: Kaempferol derivatives as antiviral drugs against the 3a channel protein of coronavirus. Planta medica 2014, 80(02-03):177. 
68. Schwarz S, Wang K, Yu W, Sun B, Schwarz W: Emodin inhibits current through SARS-associated coronavirus 3a protein. Antiviral research 2011, 90(1):64-69.

69. Shen L, Niu J, Wang C, Huang B, Wang W, Zhu N, Deng Y, Wang H, Ye F, Cen S: High-throughput screening and identification of potent broadspectrum inhibitors of coronaviruses. Journal of virology 2019, 93(12). 